\title{
Corporate Governance in Institutions Offering Islamic Financial Services
}

\section{Issues and Options}

\author{
Wafik Grais and Matteo Pellegrini
}

\begin{abstract}
This paper reviews Institutions Offering Islamic Financial Services (IIFS) corporate governance (CG) challenges and suggests options to address them. It first points out the importance of CG for IIFS, where it would require a distinct treatment from convention CG and highlights three cases of distress of IIFS. It then dwells on prevailing CG arrangements addressing IIFS' needs to ensure the consistency of their operations with Islamic finance principles and the protection of the financial interests of a stakeholders' category, namely depositors holding unrestricted investment accounts. It raises the issues of independence, confidentiality, competence, consistency and disclosure that may bear on pronouncements of consistency with Islamic finance principles. It also discusses the agency problem of depositors holding unrestricted investment accounts. The paper argues for a governance framework that combines internal and external arrangements and relies significantly on transparency and disclosure of market relevant information.
\end{abstract}

World Bank Policy Research Working Paper 4052, November 2006

The Policy Research Working Paper Series disseminates the findings of work in progress to encourage the exchange of ideas about development issues. An objective of the series is to get the findings out quickly, even if the presentations are less than fully polished. The papers carry the names of the authors and should be cited accordingly. The findings, interpretations, and conclusions expressed in this paper are entirely those of the authors. They do not necessarily represent the view of the World Bank, its Executive Directors, or the countries they represent. Policy Research Working Papers are available online at http://econ.worldbank.org. 


\section{List of Abbreviations}

AAOIFI: Accounting and Auditing Organization for Islamic Financial Institutions

BCBS: Basel Committee on Banking Supervision

BCCI: Bank of Credit and Commerce International

CAH: Current Account Holders

CB: $\quad$ Central Bank

CFI: Cooperative Financial Institutions

CFS: $\quad$ Conventional Financial Services

CG: $\quad$ Corporate Governance

CIBAFI: General Council of Islamic Banks and Financial Institutions

FDIC: Federal Deposit Insurance Corporation

FAS: $\quad$ Financial Accounting Standards

FSA: $\quad$ Financial Services Authority

ICFS: Institutions offering Conventional Financial Services

IFH: Ihlas Finance House

IIFS: Institutions offering Islamic Financial Services

IFRS: International Financial Reporting and Accounting Standards

IFSB: $\quad$ Islamic Financial Services Board

IIFM: International Islamic Financial Market

IIRA: International Islamic Rating Agency

IRR: Investment Risk Reserve

IOSCO: The International Organization of Securities Commissions

LMC: Liquidity Management Center

OECD: Organization for Economic Cooperation and Development

PER: Profit Equalization Reserve

PLS: $\quad$ Profit and Loss Sharing

PQBC: Publicly Quoted Corporation Bank

RIA: Restricted Investment Account

SME: $\quad$ Small and Medium Enterprise

SSB: Shariah Supervisory Board

UIA: Unrestricted Investment Account 


\section{Introduction $^{1}$}

Good governance is crucial to the ability of a business to protect the interests of its stakeholders. These interests may extend beyond the purely financial to the stakeholders' ethical, religious, or other values. In the case of an institution offering Islamic financial services, stakeholders expect its operations to be carried out in compliance with the principles of Shariah (Islamic Law). A corporate structure that enables such an institution to implement good governance through Shariah-compliant operations is therefore essential. ${ }^{2}$

Islamic finance helped sustain economic growth throughout the Muslim world during the Middle Ages. After a long period of lull, the last three decades witnessed its revival, notably after the first oil price shock of 1973-74. Beyond the surge in liquidity, its reemergence was prompted by the introduction of innovative Islamic financial products and a demand by Muslim populations for financial services compatible with their religious beliefs. More recently, the industry has received a new impetus that can be ascribed to a number of factors: the uneven performance of Western financial markets, a perception of increased risk for Gulf Cooperation Council capital in traditional financial markets, a renewed surge in oil prices, an expressed demand from Muslim communities in Western countries, and the development of managerial skills necessary for providing Islamic financial services. ${ }^{3}$ The global Islamic financial services industry now includes 284 institutions offering Islamic financial services (IIFS) operating in 38 countries, both Muslim and non-Muslim. ${ }^{4}$

\footnotetext{
${ }^{1}$ The authors would like to thank Arun Adarkar, Stijn Claessens, Dahlia El-Hawary, Zamir Iqbal, Luigi Passamonti, Leila Triki, and participants to meetings of the Islamic Financial Services Board and the Accounting and Auditing Organization for Islamic Financial Services for helpful comments on the issues discussed. All remaining errors are the authors'.

${ }^{2}$ Annex I provides a glossary of Arabic terms.

${ }^{3}$ According to the General Council of Islamic Banks and Financial Institutions (CIBAFI), total assets have roughly doubled in the period 1998-2001, soaring from \$134 to \$261 Billion. Source: http://www.islamicfi.com (last visited April 04, 2005).

${ }^{4}$ IIFS refers to a firm offering Islamic financial services, and includes finance houses, that offer retail commercial and investment services. This paper does not deal with Takaful (insurance) companies.
} 
Initially, IIFS developed without being clear about the legislative and regulatory framework that applied to them. ${ }^{5}$ However, their conceptual foundations and operational practices have specific features that pose challenges to regulators and call for solutions beyond the simple extension of existing legislation and regulation applying to institutions offering conventional financial services (ICFS). Consequently, a number of countries have established laws and regulations for IIFS, and international bodies have been created to adapt conventional standards and harmonize practices. ${ }^{6}$

This paper reviews IIFS' corporate governance (CG) challenges and suggests options to address them. Four main concerns motivate this attention to the CG of IIFS: (i) CG is important for economic development; (ii) the assets of IIFS are significant and growing, (iii) sound CG may be more critical for financial than other organizations, and (iv) the CG vulnerabilities of IIFS may not have received adequate attention in conventional CG frameworks. ${ }^{7}$

The activities of IIFS impact the welfare of more than $20 \%$ of the world's population, mostly in developing countries. ${ }^{8}$ In certain financial systems, IIFS may channel more than 20\% of financial flows. Moreover, IIFS provide access to financial services to social groups that would otherwise hesitate to use them. For both ICFS and IIFS, sound CG creates an enabling environment, which rewards banking efficiency, mitigates financial risks, and increases systemic stability.

Islamic capital markets, mutual funds and insurance services are also developing, but are not covered here These figures were reported in a press release by CIBAFI dated May 8, 2005, ("CIBAFI Raises the Glance toward IIFS Growth with a Unique Statistic-Based 10-Year Strategic Plan”).

${ }^{5}$ For example, in some cases the general prudential regime was extended to IIFS without recognizing any specific feature. In other cases, IIFS registered as non-bank commercial businesses. For an introduction to the principles and instruments of Islamic finance as well as regulatory arrangements applying to IIFS, refer for instance to El-Hawary, Grais, and Iqbal (2004).

${ }^{6}$ These include the Islamic Financial Services Board (IFSB), the Accounting and Auditing Organization for Islamic Financial Institutions (AAOIFI), the International Islamic Rating Agency (IIRA), the International Islamic Financial Market (IIFM) and the Liquidity Management Center (LMC). Rather than seeking to replace existing regulation, these bodies propose solutions whenever conventional regulation fails to address the distinctiveness of the Islamic financial industry.

${ }^{7}$ CG is here understood as a set of systems and processes for ensuring proper accountability, probity and transparency in the conduct of an organization's business as well as in the relationships between different stakeholders. The definition of CG will be expanded in Section III.

${ }^{8}$ According to www.adherents.com, Muslims represent 22\% of the world population (as of April 04, 2005). 
In a review of the impact of corporate governance on economic development, Claessens (2003) identifies four areas in which empirical evidence points to the positive effects of good CG on the performance of firms. First, it facilitates access to external finance. Lenders and other investors are more likely to extend financing to a business if they are comfortable with its CG arrangements, including the clarity and enforceability of creditor rights. Second, good CG tends to lower the cost of capital, by conveying a sense of reduced risk that translates into shareholders' readiness to accept lower returns. Third, good CG is proven to lead to better operational performance. Finally, it reduces the risks of contagion from financial distress. In addition to reducing the internal risk through raising investors' risk perception and willingness to invest, it increases the robustness and resilience of firms to external shocks.

The second motivation, namely, the importance of CG arrangements for financial institutions, arises out of the fiduciary nature of their activities and the likely asymmetry in access to information. ${ }^{9}$ In essence, a financial institution is a fiduciary trustee, which is entrusted with the assets of investors. It is therefore obliged to act in their best interests when holding, investing, or otherwise handling their property ${ }^{10}$. This is crucial in banking institutions, where the scope for informational asymmetries is likely to be greater than in other firms. It is difficult for an outsider to control or evaluate bank managers, given the latter's ability to influence boards, alter the risk composition of assets, or hide information on loan quality. ${ }^{11}$ The opacity of the banking system inevitably reduces the effectiveness of a competitive environment by itself to ensure good CG, as takeovers can rarely take place when insiders have an informational advantage. ${ }^{12}$

\footnotetext{
${ }^{9}$ Dewatripont and Tirole (1993) argue on the contrary that financial firms present no specific externality that differentiates them from other firms and that would justify the need for stricter regulation of financial institutions.

${ }^{10}$ In some countries, the fiduciary nature of banking is enshrined in law. For instance, the General banking Law of the Philippines states that the "fiduciary nature of banking requires high standards of integrity and performance” (Republic Act No. 8791). Also refer to Macey and O’Hara (2003) for an explanation of why fiduciary duties of directors should be extended to stakeholders other than shareholders in the case of financial firms.

${ }^{11}$ Caprio and Levine (2002), Morgan (2002).

12 In general, the disciplining power of competition is hindered in banking by limited product market competition as banks construct long-term relationships with customers. Even if product markets were fully
} 
Nevertheless, some Islamic scholars argue that IIFS should be immune to these flaws. They contend that IIFS have better CG because the moral code of Islam induces stakeholders to behave ethically. ${ }^{13}$ Nevertheless, the commitment of concerned stakeholders to Islamic religious principles cannot be taken for granted. The Nobel Laureate Albert O. Hirschman contended that "under any economic, social, or political system, individuals, business firms, and organizations in general are subject to lapses from efficient, rational, law-abiding, virtuous, or otherwise functional behavior". ${ }^{14}$ Islamic financial institutions are no exception. Indeed, IIFS are no less prone to suffer from breaches of fiduciary responsibilities or the consequences of asymmetric information. The history of Islamic finance shows that cases of CG failures have features in common with conventional banking scandals, such as collusion of the board with management, external and internal audit failure, neglect of minority shareholders' interests, imprudent lending, and excessive risk taking by management. ${ }^{15}$

The third motivation of this paper is that the practices of IIFS raise specific CG challenges. While a number of problems are common to all financial institutions, and can be mitigated by existing regulations, two broad sets of CG issues are specific to IIFS. ${ }^{16}$ The first arises from the need to reassure stakeholders that the institution's activities fully comply with the precepts of Islamic jurisprudence. ${ }^{17}$ Ultimately, the core mission of an Islamic financial institution is to meet its stakeholders' desire to conduct their financial business according to Shariah principles. ${ }^{18}$ There must, therefore, be CG mechanisms to assure them that the necessary safeguards are in place. The same stakeholders also need to be assured that the firm will nonetheless actively promote their financial interests, and

competitive, capital markets would still ill-function due to waves of irrational optimism and pessimism that result in shareholders looking at immediate revenues rather than the long-term ability of firms to pay dividends. For more see Levine (2004) and Prowse (1998).

${ }^{13}$ Sarker (1999).

${ }^{14}$ Hirschman (1970).

${ }^{15}$ For some examples of IIFS CG failures, refer to section II.

${ }^{16}$ We refer to OECD Principles of CG and BCBS Standards for Enhancing CG for Banking Organizations. This presents the additional advantage of favoring the integration of IIFSs into global markets. This position is also supported by international standard setters like the IFSB and AAOIFI.

${ }^{17}$ Islamic jurisprudence is also known as Fiqh. It covers all aspects of life: religious, political, social and economic. It is mainly based on interpretations of the Quran and Sunna (sayings and deeds of the prophet).

${ }^{18}$ For a glossary of terms, please refer to Annex I 
prove to be an efficient, stable, and trustworthy provider of financial services. In practice, depositors and borrowers need to feel confident that the types of liabilities and assets that IIFS deal with are competitive and offer a risk-return trade-off acceptable to their clients. This combination of requirements of Shariah compliance and business performance raises specific challenges and agency problems, and underlines the need for distinctive CG structures. ${ }^{19}$

The following section begins with a review of three cases of IIFS distress. They illustrate issues specific to IIFS, such as failure to comply with the Shariah, capture of the institution by special interests, and weak public policy. Section II considers IIFS' emphasis on stakeholders' value and the relevance to such institutions of CG arrangements based on shareholder value. Section III identifies shortcomings in prevailing CG arrangements in protecting stakeholders' ethical interests in IIFS and offers suggestions to address vulnerabilities. Section IV reviews stakeholders' financial interests and arrangements to protect them. Section $\mathrm{V}$ presents the conclusions of the paper.

\section{Three Cases of Distress}

Three cases illustrate possible CG weaknesses in IIFS. ${ }^{20}$ The first relates to the failure to ensure compliance with stakeholders' religious beliefs. The other two cases show how poor CG structures, both internal and external, can affect investors' finances, particularly those of the relatively unprotected unrestricted investment account (UIA) holders, as well as the stability and sustainability of the Islamic financial industry.

A central feature of the CG of an Islamic financial institution is ensuring Shariah compliance. To reassure stakeholders, the institution generally sets up a Shariah

\footnotetext{
${ }^{19}$ This paper focuses on those financial issues specific to IIFS, such as the existence of investment accounts, profit-smoothing instruments and poor ring-fencing of funds provided by different stakeholders.

${ }^{20}$ Other notable examples, not mentioned in this chapter, include the Kuwait Finance House engulfment in the Souk al Manakh crash (1986-87); the liquidation of the International Islamic Bank of Denmark due to excessive financing exposure to a single client (1986); and the failure of the Islamic Money Management Companies in Egypt (1988-89).
} 
supervisory board (SSB) or retains the services of Shariah advisors that certify the Shariah compliance of the financial transactions. However, the ability of the SSB or the Shariah advisors to fulfill the mandate may be constrained by the volume of activity, their access to monitoring systems, the complexity of financial transactions, or the extent of their independence. ${ }^{21}$ These factors may have been at play during the collapse of the Bank of Credit and Commerce International (BCCI), which involved several IIFS. Five IIFS deposited significant resources with the BCCI, a leading CFS business, with the understanding that they would be invested in commodity contracts, in compliance with Shariah principles. ${ }^{22}$ However, following the failure, Price Waterhouse, BCCI's auditor, reported that "there is no evidence to suggest that the bank actually entered into any commodity contracts". ${ }^{23}$ The discovery was important, given the level of exposure of the concerned IIFS in the BCCI. Reportedly, one of the IIFS involved had 25\% of its assets placed with the BCCI. ${ }^{24}$ The size of exposure suggests a weak due diligence process in the verification of Shariah compliance. More generally, the case illustrates the limits a SSB may face in discharging its mission.

The 2001 collapse of Ihlas Finance House (IFH) of Turkey illustrates the consequences of capture by special interests in an environment of weak internal and external checks. The largest of the Turkish IIFS, with over $40 \%$ of the sector deposits, IFH was liquidated by the Turkish Banking Regulation and Supervision Agency because it had illegally appropriated almost \$1billion, virtually the entire value of the deposit base, through connected lending to shareholders, concealed by the rapid growth of deposits. Concentrated ownership and control had permitted an incentive system biased in favor of shareholders. When the bank was liquidated, the misappropriation of funds was so large that the bank was unable to pay back its 200,000 depositors. ${ }^{25}$

\footnotetext{
${ }^{21}$ Section IV expands on the challenges of Shariah CG.

${ }^{22}$ The IIFS in question were the Faisal Islamic Bank of Egypt, the Dubai Islamic Bank, the Khartoumbased Tadamon Islamic Bank, the Qatar Islamic Bank and Kuwait Finance House, as reported by The Asian Wall Street Journal: “BCCI Creditors Granted More Time” (April 9, 1992).

${ }^{23}$ As reported in the Washington Post: "Exposing BCCI Faults: Audit, Testimony Show Disregard for Rules” (August 12, 1991).

${ }^{24}$ Financial Times: “BCCI Shutdown. Response Muted from Islamic Institutions” (August 8, 1991)

${ }^{25}$ Starr and Yilmaz (2004).
} 
IFH, like other Turkish Special Finance Houses, was not covered by deposit insurance. ${ }^{26}$ The failure created panic among UIA holders that threatened to bring down other IIFS in the country. In spite of the reported sound fundamentals of the sector, and assurances by Turkish regulators as well as the Association of Special Finance Houses on the good health of the system, runs eroded 63\% of total deposits in IIFS within the first quarter of 2001. ${ }^{27}$ Compounding the IFH failure was the inability of IIFS to manage liquidity in the absence of Shariah-compliant secondary markets. Overall, the failure of IFH revealed the contagion risks to the financial stability and reputation of other IIFS because of poor CG.

The 2003 failure of the Patni Cooperative Credit Society of Surat in India provides an example of how weakness in the external institutional environment can affect the governance of IIFS. External CG, includes the legal, regulatory and conflict resolution framework. As an example, the Reserve Bank of India Act, by requiring that deposit-taking institutions maintain interest-bearing accounts with the central bank, effectively prevents the functioning of IIFS as deposit taking businesses. ${ }^{28}$ Most IIFS have chosen the organization form of a cooperative and, as such, face two sets of conditions that magnify the challenges of their operations. Firstly, they can operate only in the state in which they are licensed, as prescribed by the Cooperative Societies Act. ${ }^{29}$ Secondly, they have to observe conventional prudential standards on capital adequacy, income recognition, and asset classification and provisioning, all of which extend to financial cooperatives. The cumulative effect of these conditions complicates the intrinsic challenge of liquidity management for IIFS, given their exclusion from conventional money markets. They also limit the potential scale of the firms' activities and affect their

\footnotetext{
${ }^{26}$ IIFS investment deposits cannot in principle be insured because this would insulate UIA holders from credit and market risks, thus violating the risk-sharing nature of investments, prescribed by Fiqh jurists.

${ }^{27}$ Starr and Yilmaz (2004).

${ }^{28}$ To acquire bank status, Indian IIFS would be required to maintain a deposit account with the central bank, on which they would earn interest. A strict interpretation of this rule forces them to opt for the status of non-banking financing company to preserve their Islamic (interest-free) nature. For more, refer to Khan (2001). Regulations applying to IIFS in India are currently under review.

${ }^{29}$ Bagsiraj (2002), and Kahn (2001).
} 
competitive position. ${ }^{30}$ The management of the Patni Cooperative may therefore have been induced to take excessive risks, resulting in an unsustainable level of nonperforming loans. ${ }^{31}$

\section{Shareholders' versus Stakeholders' Value: Corporate Governance in Islamic and Conventional Financial Institutions}

Widely publicized mismanagement scandals have focused attention on the relevance of CG for the protection of the rights of shareholders' as well as of other stakeholders. $^{32}$ Misconduct in financial businesses not only creates widespread investment losses, but also shakes investors' confidence, and raises doubts about the stability of the international financial system. Equally important, they damage the value of all other stakeholders, such as creditors, suppliers, consumers, employees, and pensioners, and of communities at large. They affect the livelihoods of the victims of the businesses' financial distress. ${ }^{33}$ The consequences of weak CG in a financial institution are, therefore, not only financial, but also entail heavy costs in social and human terms. In contrast, sound CG facilitates access to external finance, improves the firms' operational performance, enhances systemic financial stability, and contributes to the welfare of the community.

Over time, growing concerns about the impact of business performance on groups other than shareholders have led to measures to protect stakeholders being superposed on what continues to be essentially a shareholder value based framework. Conventional CG does not yet offer an analytical framework to internalize stakeholders' protection within the objectives of the firm. It adopts a pragmatic approach that offers rules that may not

\footnotetext{
${ }^{30}$ Ramesha (2003). There is also a different school of thought that maintains that prudential standards conceived for shareholding financial companies can be applied to financial cooperatives with no negative impact on the performance of the latter.

${ }^{31}$ For more refer to Bagsiraj (2002). As of the final drafting of this paper, no decision has yet been taken on the liquidation by Patni bank by the Reserve Bank of India.

${ }^{32}$ At the end of 2004, the insurance industry was the target of accusations by Eliot Spitzer, New York's Attorney General, for price-fixing, bid-rigging and undisclosed payments. See The Economist "Reprehensible - The Insurance Industry" (October 23, 2004).

${ }^{33}$ These would be stakeholders with a contractual relationship with the firm. The notion of stakeholder could be extended to parties who do not have a contractual relationship with the firm and who would be affected by the externalities of its decisions. For example, communities downstream of a new dam project may be affected by biodiversity damage to their environment.
} 
necessarily be consistent with the incentives driving whoever controls the business. The conceptual difficulty of conventional CG in fully integrating the interests of nonshareholding stakeholders diminishes its ability to design incentives that can be adapted to IIFS. Indeed, the latter have always assigned a much higher priority than CFS firms to non-financial interests as well as given more weight to the interests of non-shareholding stakeholders.

The cornerstone of CG arrangements for conventional businesses is the protection of shareholders' rights. From this perspective, the question is how to secure the rights of ownership once the investors' financial resources have been relinquished. The answer to this question may lie in the configuration of incentives for managers, control retention by owners, and the reliability of the legal system. ${ }^{34}$ Shleifer and Vishny (1996) argue that “corporate governance deals with the agency problem: the separation of management and finance". They then point out that "the fundamental question of corporate governance is how to assure financiers that they get a return on their financial investment”. While the reference to finance and financiers may also include creditors, the primary focus of their review is on shareholders' protection. Indeed the distinction of management and finance is targeted at the separation of ownership and control. Thus, the major feature of shareholders' value based CG is the design of incentives that lead managers to pursue the maximization of shareholders’ value.

Conventional CG does not overlook stakeholders other than shareholders. Shleifer and Vishny (1997) acknowledge the impact of corporate decisions on multiple stakeholders. Such awareness is generally either based on agnostic empirical observations or social responsibility considerations. For example, Tirole (1999) holds that "managerial decisions do impact investors, but they also exert externalities on a number of natural stakeholders who have an innate relationship with the firm”. He follows up by asking "why (one) should ignore the natural stakeholders and favor the investors, who are

\footnotetext{
${ }^{34}$ The choice of the distribution and use of owners' control may be affected by the extent to which ownership is atomistic or concentrated. However, while the protection of minority shareholders' rights compounds the difficulties stemming from the agency problem, the conceptual framework remains the same.
} 
“stakeholders by design”, by giving them full control rights and by aligning managerial compensation with their interests”.

Trying to internalize, through incentives, stakeholders' value in the decisionmaking process of corporations is a daunting challenge. Tirole (1999) examines whether the managerial incentives and control structure in a shareholder value framework can be adapted to include other stakeholders' interests. Managerial incentives are difficult to design if the firm's objective shifts from the maximization of shareholders' value to that of the "aggregate welfare of the stakeholders". The latter has no clear widely accepted measure or market value. Accordingly, it does not provide a foundation for linking incentives with performance. Falling back on a profit-based compensation system is likely to lead to biased decisions, as managers would pursue profitability at the expense of other objectives. Sharing control among stakeholders with heterogeneous interests in a joint venture would seriously impede its efficacy. ${ }^{35}$ Similarly, relying on enlarging management's fiduciary duty to various stakeholders may leave it with too much power to pursue its own objectives. ${ }^{36}$ Thus, trying to design managerial incentives to accommodate stakeholders’ interests is more complex than might at first appear.

Public policy overcomes the limitations of available analytical frameworks to deal with stakeholders' value by adopting pragmatic approaches. The outcome is arrangements that generally strengthen transparency and limit blatant misconduct. Standards have emerged and principles have been codified, with significant contributions notably by the OECD and the BCBS. The OECD defines CG as "a set of relationships between a company's management, its board, its shareholders and other stakeholders. Corporate Governance also provides the structure through which the objectives of the company are set, and the means of attaining those objectives and monitoring performance are determined". ${ }^{37}$ This definition provides important attributes of CG and emphasizes transparency. However, it does not directly deal with the intrinsic issue of the business

\footnotetext{
${ }^{35}$ Hansmann (1996) quoted in Tirole (1999). However some may consider this a much lesser evil than the outcome of decisions emanating from undivided control by shareholders.

36 "Management can almost always rationalize any action by invoking its impact on the welfare of some stakeholder”. See Tirole (1999).

${ }^{37}$ OECD (2004)
} 
objectives that should guide the distribution of rights and responsibilities within the corporation. Indeed, the objectives of a corporation's founders', whether these be the increase of shareholders' value or the pursuit of stakeholders' interest, can be expected to affect such a distribution and shape the institutional structure and systems. In particular, the distribution of rights and responsibilities among shareholders and other stakeholders would be driven by the interests of whoever establishes the corporation and subsequently controls it.

Stakeholders' value is central to the IIFS, and is generally incorporated in mission statements (Annex II). ${ }^{38}$ A selection of mission statements suggests that IIFS focus on two broad sets of objectives: (a) compliance with Shariah principles, and (b) provision of excellent services. Shariah compliance appears to fall into three categories. The first one and most widely understood includes the conduct of financial business in accordance with the prohibition of Riba' and Gharar. ${ }^{39}$ The second appears to cover the furthering of Islam's social objectives, in particular the promotion of social benevolence. ${ }^{40}$ In this regard, the Central Bank of Jordan states in its Banking Law that one of the objectives of Islamic banking is the provision of "services aimed at reviving social solidarity organized on the basis of mutual benefit". ${ }^{41}$ The third aspect of Shariah compliance is the development and promotion of an integrated Islamic financial system, or the "eventual institution of an elaborate and comprehensive banking system based on the rules of Islamic Shariah". ${ }^{42}$ Subsumed under the set of Shariah objectives of providing excellent services are: (a) service to the community as a whole, referring primarily but not exclusively to the Muslim community (Ummah); (b) promoting the interests of related

\footnotetext{
${ }^{38}$ Annex II compares the mission statements of 22 leading IIFS and ICFS.

${ }^{39}$ Compliance with Shariah principles appears explicitly in almost all IIFS mission statements. The explicit reference to Riba' or Gharar is less frequent. Riba' is mentioned in the mission statement of Dubai Islamic Bank. Islamic Bank of Thailand mentions "not being tied with interest".

${ }^{40}$ The social nature of Islamic finance emerges most clearly in the practices of Zakat and Qard Hassan. Zakat is a tax on wealth while Qard Hassan are zero-return beneficence loans to be made to the needy. See for example the goals of ABC Islamic Bank (E.C.) and Dubai Islamic Bank. Badr-Forte Bank of Russia mentions "social justice and harmony". Meezan Bank limited of Pakistan refers to the "implementation of an equitable economic system, providing a strong foundation for establishing a fair and just society for mankind".

${ }^{41}$ Article 50a of the Banking Law of Jordan, Law No. 28 of 2000, as amended by Temporary Law No.46 of 2003. Available at www.cbj.gov.jo/

${ }^{42}$ See the mission statements of Badr-Forte Bank of Russia, Al Baraka Islamic Bank (Bahrain), and Faisal Islamic Bank of Egypt.
} 
parties, including shareholders, depositors, and employees; and (c) the developing the professional and ethical qualities of management and staff. ${ }^{43}$

IIFS' CG arrangements are mostly modeled along those of the conventional shareholder corporation, in spite of the explicit mandate to promote social welfare and pursue stakeholders' value. This configuration leads to a distribution of rights and responsibilities that essentially leaves control with shareholders. The most notable variation in CG structure is the presence of a Shariah board of scholars and a Shariah review unit that ensure compliance with the Islamic law. Shariah compliance decisions affect all IIFS stakeholders. In addition, internal stakeholders such as investment account holders, and external governance structures such as accounting would perhaps be distinctive features of an Islamic financial institution Nevertheless, IIFS' CG practices and structures are mainly fashioned along those of a CFS firm. (Figure I). ${ }^{44}$

\footnotetext{
43 This is referred to as "maximizing our clients and shareholders value" (Al Baraka Islamic Bank), "achieve optimum and not maximum profits, for the mutual benefit of customers and the bank" (Dubai Islamic Bank), “constantly strive to protect (its) shareholders' interest” (Bank Islam Malaysia Berhad), or "optimizing the stakeholders' value” (Meezan Bank limited Pakistan).

${ }^{44}$ IIFS operate mostly in jurisdictions where legal protection could be strengthened. The prohibition of Riba' and Gharar translates into risk-sharing arrangements that may leave stakeholders in uncertainty as to the security of their assets. Furthermore undivided control with shareholders can create biased decisionmaking, see Tirole (1999)
} 


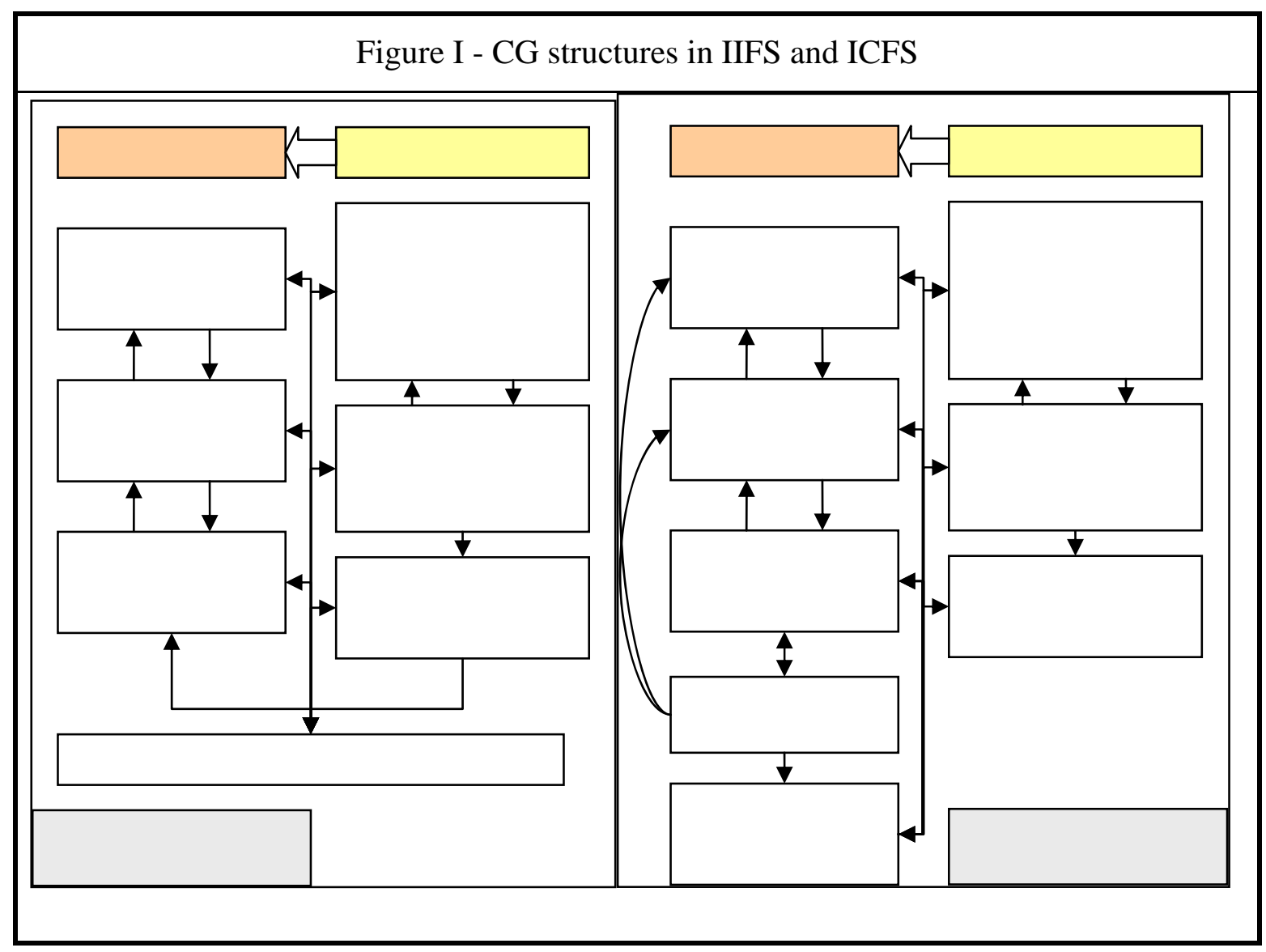

Since IIFS' configurations mostly identify shareholders as the residual claimants of the institutions, the internalization of stakeholder value may in the short-term require solutions that do not necessarily reflect the incentives enshrined in the firm's governance system and processes. However, the identification of IIFS' mission as the promotion of the welfare of all stakeholders should lead to the gradual adaptation of ownership structures to permit the alignment of governance arrangements with the incentives of all stakeholders. $^{45}$

\footnotetext{
${ }^{45}$ Table I provides a simplified contrast of the issues in shareholder and stakeholder centered perspectives of CG and expands on positive and normative illustrations of CG in IIFS.
} 
Table I - Shareholder versus Stakeholder Centered CG Issues

\begin{tabular}{|l|l|l|l|}
\hline Model & Control & Fiduciary Duty & Firm's Objective \\
\hline $\begin{array}{l}\text { Shareholders } \\
\text { Centered }\end{array}$ & With shareholders & To shareholders & $\begin{array}{l}\text { Maximize shareholders' } \\
\text { wealth }\end{array}$ \\
\hline $\begin{array}{l}\text { Stakeholders } \\
\text { Centered }\end{array}$ & $\begin{array}{l}\text { Stakeholders have right } \\
\text { to participate in } \\
\text { decisions }\end{array}$ & To all stakeholders & $\begin{array}{l}\text { Promote the interests of } \\
\text { all stakeholders }\end{array}$ \\
\hline $\begin{array}{l}\text { IIFS Current } \\
\text { Practice }\end{array}$ & With shareholders & $\begin{array}{l}\text {-To all stakeholders } \\
\text {-To board of Shariah } \\
\text { scholars }\end{array}$ & $\begin{array}{l}\text { - Compliance with } \\
\text { Islamic Shariah } \\
\text { - Excellence of service to } \\
\text { all stakeholders }\end{array}$ \\
\hline IIFS Options & $\begin{array}{l}\text { Stakeholders have right } \\
\text { to participate in } \\
\text { decisions }\end{array}$ & $\begin{array}{l}\text {-To all stakeholders } \\
\text {-To board of Shariah } \\
\text { scholars }\end{array}$ & $\begin{array}{l}\text { - Compliance with } \\
\text { Islamic Shariah } \\
\text { - Excellence of service to } \\
\text { all stakeholders }\end{array}$ \\
\hline Source: Derived from Boatright, J. R. (2002) and extended to include IIFS. \\
\hline
\end{tabular}

\section{Shariah Compliance and Stakeholders' Ethical Interests}

The Governor of the Bahrain Monetary Agency conveyed the sense of IIFS’ roots in stating that "Islamic banks have grown primarily by providing services to a captive market, people who will only deal with a financial institution that strictly adheres to Islamic principles". ${ }^{46}$ This pledge to conduct activities in accordance with Shariah principles entails that IIFS would: (i) not engage in interest-based debt transactions, (ii) not conduct a purely financial transaction disconnected from real economic activity ${ }^{47}$, (iii) not participate in a transaction where there is exploitation of any party, and (iv) not participate in activities regarded as harmful to society. Failure of individual institutions to ensure compliance would entail a reputational risk for the Islamic finance industry. ${ }^{48}$ To mitigate such risk, IIFS have created CG structures and processes that reassure

\footnotetext{
46 As reported by Middle-East-Online.com on February 17, 2004 . http://www.middle-eastonline.com/english/bahrain/?id $=8922=8922 \&$ format $=0$ (last visited April 11, 2005)

${ }^{47}$ This concept is sometimes referred to as "materiality".

${ }^{48}$ In a survey of depositors' preferences, Chapra and Ahmed (2002) show that $81.7 \%$ of surveyed depositors in Bahrain would withdraw funds from their Islamic bank and chose an alternative Islamic bank, should failure to comply with to Shariah emerge. In the case of Bangladesh, the percentage is 46.6. In Sudan, it raises to 94.6.
} 
stakeholders on the Shariah compliance of all transactions. A widely adopted approach is to have independent bodies certify such compliance.

Each Islamic financial institution has in-.house religious advisers, collectively known as Shariah Supervisory Board (SSB), as part of the internal governance structure of the institution. ${ }^{49}$ In some countries, authorities have created oversight arrangements, such as Shariah boards or Islamic banking departments within supervisory agencies. These usually operate in conjunction with private independent market agents familiar with Islamic finance.

SSBs' tasks may vary according to provisions stipulated in the articles of association of the institution or by national regulators. Corporate charters would entrust SSBs with ex-ante monitoring and the calculation of Zakat. International and national regulators often publish guidelines for SSBs, which refer to their general duty to ensure Shariah compliance of transactions and, less frequently, provide guidelines on competences, composition and decision-making (Table II). ${ }^{50}$

In principle, SSBs' prerogatives lie in five main areas: certification of permissible financial instruments through fatwas (ex-ante Shariah audit), verification of transactions' compliance with issued fatwas (ex-post Shariah audit), the calculation and payment of Zakat, disposal of non-Shariah compliant earnings, and advice on the distribution of income or expenses among the bank's shareholders and investment account holders. ${ }^{51}$ Each SSB issues a report to certify the Shariah compliance of all financial transactions. This report is usually an integral part of the institution's annual report.

\footnotetext{
${ }^{49}$ They exist in all Islamic countries with the exception of Iran, where compliance of the whole banking system with Shariah is guaranteed and monitored by the central bank.

${ }^{50}$ We here mention only those countries where authorities have implemented laws, acts or issued circulars and regulations on internal Shariah Supervisory Boards. Annex III details the legal bases and the provisions of these regulations.

${ }^{51}$ A Fatwa is a religious edict or proclamation. It is a legal opinion issued by a qualified Muslim scholar on matters of religious belief and practice.For more, see Briston and El-Ashker (1986) and Abdel Karim (1990). For an explanation of Zakat refer to footnote 40.
} 


\begin{tabular}{|c|c|c|c|c|c|}
\hline \multicolumn{6}{|c|}{ Table II - Regulations on Internal Shariah Advisory** } \\
\hline Country & $\begin{array}{l}\underline{\text { SSB terms }} \\
\text { of reference }\end{array}$ & $\begin{array}{c}\underline{\mathrm{SSB}} \\
\text { composition }\end{array}$ & $\frac{\underline{\text { SSB }}}{\frac{\text { decision- }}{\text { making }}}$ & $\begin{array}{c}\frac{\mathrm{SSB}}{\mathrm{SPpointment}} \\
\underline{\text { \& dismissal }}\end{array}$ & 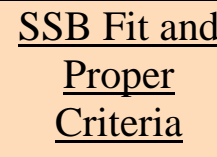 \\
\hline Bahrain & $\checkmark$ & $\checkmark$ & unspecified & $\checkmark$ & $\checkmark$ \\
\hline DIFC* & $\checkmark$ & $\checkmark$ & unspecified & $\checkmark$ & $\checkmark$ \\
\hline Indonesia & $\checkmark$ & unspecified & unspecified & $\checkmark$ & $\checkmark$ \\
\hline Jordan & $\checkmark$ & $\checkmark$ & $\checkmark$ & $\checkmark$ & unspecified \\
\hline Kuwait & $\checkmark$ & $\checkmark$ & $\checkmark$ & unspecified & unspecified \\
\hline Lebanon & $\checkmark$ & $\checkmark$ & unspecified & $\checkmark$ & unspecified \\
\hline Malaysia & $\checkmark$ & unspecified & unspecified & unspecified & $\checkmark$ \\
\hline Pakistan & $\checkmark$ & $\checkmark$ & unspecified & $\checkmark$ & $\checkmark$ \\
\hline Philippines & $\checkmark$ & $\checkmark$ & unspecified & unspecified & $\checkmark$ \\
\hline Thailand & $\checkmark$ & $\checkmark$ & unspecified & $\checkmark$ & $\checkmark$ \\
\hline U.A.E. & $\checkmark$ & $\checkmark$ & unspecified & $\checkmark$ & unspecified \\
\hline \multicolumn{6}{|c|}{$\begin{array}{l}\text { * Dubai International Financial Centre } \\
* * * \text { Annex III details the legal bases and the provisions of these regulations }\end{array}$} \\
\hline Source: Official & & & 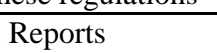 & & \\
\hline
\end{tabular}

In addition to Shariah boards, most IIFS, particularly those complying with AAOIFI standards, have established another internal Shariah review structure, namely, Shariah Review units. ${ }^{52}$ These units are independent of other departments or are an integral part of the Internal Audit and Control Department. The array of tasks that they perform is parallel to that of audit departments: reviewers generally use all necessary powers to ascertain that all financial transactions implemented by management comply with SSB rulings. ${ }^{53}$ In some instances Shariah review units have exclusive competence

\footnotetext{
${ }^{52}$ In AAOIFI member countries and banks adhering to the organization, internal Shariah review is prescribed by Governance standard 3. In Pakistan, it is regulated by Annexure-III to IBD Circular No. 02 of 2004.

${ }^{53}$ In this respect, the role of the internal review unit is limited to a complementary ex-post monitoring. This makes its task secondary, if more focused and defined, to that of the SSBs, which are the ultimate arbiters in matters of Shariah compliance.
} 
on ex-post facto monitoring. ${ }^{54}$ These units and SSBs face similar challenges, relating, in particular, to independence, and competence.

Beyond internal arrangements, the broader Shariah governance framework may include features put in place by regulators, as well as the provision of financial information services to persons outside the institution. Among regulatory arrangements, centralized SSBs are the most noteworthy in relation to Shariah governance. While there are significant differences across countries, centralized SSBs are usually concerned with ex-ante monitoring, mostly understood as standardization of Shariah interpretation, and ex-post monitoring of Shariah compliance. They are also concerned with issues relating to upholding Shariah compliance, and offer arbitration and recourse to settle Shariah disputes between members of the same SSB. ${ }^{55}$

\begin{tabular}{|l|c|c|}
\hline \multicolumn{3}{|c|}{ Table III - External Shariah CG institutions by country* } \\
\hline Country & $\begin{array}{c}\text { Centralized SSB or High Shariah } \\
\text { Authority or Fatwa Board }\end{array}$ & Islamic Rating Agency \\
\hline Jordan & No & No \\
\hline Malaysia & $\checkmark$ & $\checkmark$ \\
\hline Sudan & $\checkmark$ & No \\
\hline Bahrain & No $\dagger$ & No $\dagger$ \\
\hline Kuwait & $\checkmark$ & No \\
\hline Pakistan & $\checkmark$ & No \\
\hline UAE & $\checkmark$ & No \\
\hline Indonesia & $\checkmark$ & \\
\hline $\begin{array}{l}\text { * Annex IV details the names and powers of these departments/authorities. } \\
\text { Bahrain is the seat of the IIFM and the IIRA that respectively set standards for Islamic jurisprudence and rate Islamic instruments on } \\
\text { an international scale. }\end{array}$ & & \\
\hline Source: Official country websites and central bank Annual Reports. & \\
\hline
\end{tabular}

${ }^{54}$ This is the case of large IIFS where the SSBs may not be able to assess large volumes of transactions. Therefore, separate Shariah control departments have been established. This seems to be the case in al Rajhi Banking and Investment Corporation and Dubai Islamic Bank.

${ }_{55}$ Annex IV presents names and powers of these organizations. It focuses in particular of the powers of central SSBs. 
Private mechanisms for the external monitoring of Shariah compliance are limited. In particular, private rating agencies have not yet developed the necessary skills or found enough incentives to monitor IIFS' Shariah compliance. “Islamic rating” has so far been the exclusive domain of government-sponsored organizations such as the IIRA and the Malaysian Rating Corporation. Likewise, other external actors with an interest in Islamic finance, such as financial media and external auditors, are still generally less concerned with assessments of Shariah compliance. ${ }^{56}$

The functioning of SSBs raises five main CG issues: independence, confidentiality, competence, consistency and disclosure. The first issue concerns the independence of the SSB from management. Generally, members of an SSB are appointed by the shareholders of the institution, represented by the board of directors to which they report. As such, they are employed by the institution, and their remuneration is proposed by the management and approved by the board. The SSB members' dual relationship with the financial institution, as providers of remunerated services and as assessors of the nature of operations, could create a conflict of interest.

The issue of confidentiality arises from the practice of Shariah scholars often sitting on the SSBs of several IIFS, thereby gaining access to proprietary information of possibly competing institutions.

The third issue is competence. In performing their function, Shariah scholars are expected to be familiar with Islamic law and to have financial expertise. In practice, very few scholars are well-versed in both disciplines.

The fourth issue is the consistency of judgment across IIFS, over time or across jurisdictions, within the same institution. Such consistency would help to promote the customer's confidence in the industry and the enforceability of contracts. Conflicting

\footnotetext{
${ }^{56}$ A notable exception is the multiplication of Stock Market Islamic Indices whose major contribution is the identification of halal investments Halal conveys goodness and by extension has taken the meaning of "permissible".
} 
opinions on the admissibility of specific financial instruments or transactions would hurt business confidence and market efficiency. ${ }^{57}$

Finally, disclosure of all information relating to Shariah advisory functions would strengthen the credibility that the offered services are essentially distinct from conventional ones and, furthermore, promote market discipline.

A SSB within an IIFS has the advantage of being close to the market. A competent and independent SSB, empowered to approve new Shariah conforming instruments, would facilitate innovation within the firm. In issuing its fatwas, the SSB could be guided by standardized contracts and practices that could be harmonized by an international standard-setting self-regulatory professionals' association. Such an approach could ensure consistency of interpretation and enhance the enforceability of contracts before civil courts. Review of transactions would mainly be entrusted to internal review units, which in collaboration with external auditors, would be responsible for issuing an annual opinion on the Shariah compliance of the transactions. This process would be sustained by reputable agents, like rating agencies, stock markets, financial media, and researchers that would channel signals to market players. Such a framework would also enhance public understanding of the requirements of Shariah, and lead to a more effective participatory role by the stakeholders in the activities of the institution.

\section{Stakeholders' Financial Interests}

Given that the core mission of a financial institution is to enable its stakeholders to pursue their financial interests, the CG arrangements for IIFS cannot underestimate the importance of having a framework that credibly protects these interests while not breaching their values. We focus attention here on three main categories of stakeholders, namely, shareholders, depositors, and borrowers.

\footnotetext{
${ }^{57}$ A typical example is the financing of leisure activities, which is regarded as haram only by some Fiqh scholars. Moreover, Islamic jurisprudence is based on different schools of thought that may vary from country to country (the Shiah branch and the Sunni branch, which in turn includes the Madhahib, Shafie, Hanafi, Hanbali and Maliki traditions).
} 
The prevailing organizational structure of IIFS is that of a shareholding company. Their CG arrangements, therefore, appear similar to those of businesses offering conventional financial services, with the conventional focus on agency problems between shareholders and management (Figure I). ${ }^{58}$ However, they may not have effectively incorporated incentives to protect other stakeholders' financial interests, in particular those of unrestricted investment account (UIA) holders.

Generally, IIFS offer three broad categories of deposit accounts: current, unrestricted investment, and restricted investment. ${ }^{59}$ Each category raises some CG issues, but those of unrestricted investment account (UIA) holders may be the most challenging. Essentially, it is the asymmetry between the extent of these depositors' participation in bearing investment risks and of their ability to influence the operations of the institution.

UIA holders are often the most important category of IIFS depositors. They enter into a mudaraba contract with the financial institution to manage their funds. ${ }^{60}$ The institution places these funds in investment pools, and profits on investments, if any, are distributed at maturity according to the profit and loss sharing (PLS) ratio specified in the contract. The UIA holders, and not the IIFS, bear the risk of a poor performance of the investment pool, except for misconduct on the part of the financial institution. ${ }^{61}$ Thus, UIA holders are stakeholders akin to shareholders. They are principals entrusting their resources to an agent, the financial institution's management - with the significant difference that, in their case, the agent is appointed by another principal, namely, the shareholder.

\footnotetext{
${ }^{58}$ Concentrated ownership in private IIFS, or state ownership in others point to the need to pay attention to the protection of small shareholders and that of state assets respectively.

${ }_{59}$ Most IIFS also offer savings accounts. However, they usually fall in either the category of term investments or in that of current accounts. We therefore only distinguish between investment deposits and current account deposits.

${ }^{60}$ The case of Wakalah UIAs, which are based on an agency relationship with the IIFS earning a flat fee, rather than a share of profits, is not considered here.

${ }^{61}$ This risk-sharing feature has led some to argue that UIA are not liabilities for the IIFS and accordingly they should not be required to meet the same capital requirements as ICFS. In particular, the credit and market risk would fall on depositors, while the bank would only be subject to operational risk.
} 
The IIFS practice of commingling shareholders' and depositors' resources in investment pools can raise the possibility of conflict of interest. The management's discretion in the configuration of the pools and in the investments made from them, can result in differential treatment of various stakeholders. Moreover, the practice may reduce the transparency of IIFS' compliance with their clients' investment objectives. Accordingly, regulatory authorities may need to prescribe disclosure rules, and possibly firewalls and sanctions for breaches. This is of paramount importance to UIA holders, whose funds are normally common-pooled with those of shareholders.

IIFS generally create reserve funds to smooth the returns to UIA holders or protect their principal in case of adverse developments in the performance of the investment portfolio. ${ }^{62}$ IIFS consider these funds important to deal with competitive pressure from ICFS and other IIFS. While in principle, returns to UIA holders are supposed to vary according to IIFS performance, poor returns may induce UIA holders to transfer their funds to a better performing institution. To mitigate such a risk, IIFS set up profit equalization reserves and use them in periods of poor performance to complement the returns that would be due to UIA holders. The reserves are fed by retaining earnings to UIA holders in periods of high returns on investment. Similar arrangements help the IIFS protect the principal of UIA holders. A special risk investment reserve is used for compensating a loss of principal resulting from poor investment results. The use of profit equalization and risk investment funds raises issues pertaining to the governance of these funds and the protection of UIA holders' rights. In particular, the practice of profit equalization may convey an inaccurate view on the actual performance of the financial institution, compounding the asymmetry of information available to UIA holders and management.

Widely available and affordable financial information can enhance the effectiveness of official and private monitoring of financial businesses' performance. It promotes transparency and supports market discipline, two important ingredients of

\footnotetext{
${ }^{62}$ These reserves are generally known as Profit Equalization Reserves (PER) and Investment Risk Reserves (IRR). We follow AAOIFI's definition in Financial Accounting Standard (FAS) 11.
} 
sound CG to protect stakeholders' financial interests. Financial information may be particularly important for IIFS because of the private equity nature of UIAs and the assumption that UIA holders have more at stake than conventional depositors. UIA holders could therefore be expected to have a heightened interest in directly monitoring the institution's performance. However, this requires an institutional infrastructure that facilitates the production of accurate financial information, the availability of agents that can interpret and disseminate it, as well as arrangements to protect its integrity. On all these counts, the Islamic financial industry may be facing challenges. The existing limited infrastructure reduces the role that information flows can play in promoting competition and market activities that would induce managers to adopt sound CG practices.

Of particular relevance to the financial information infrastructure is a chart of accounts for businesses to organize and produce credible financial statements. To enable IIFS to achieve this, the accounting profession has developed standards, at both the national and international levels. An increasing number of countries have adopted the International Financial Reporting and Accounting Standards (IFRS) in the wake of an apparent consensus to promote international convergence. However, these standards are designed for conventional businesses, including ICFS. As for IIFS' case, their practice of setting up reserve funds to smooth profit distribution and protect the UIA holders' principal, and the commitment to distribute Zakat, are among the features that make the IFRS not wholly suitable for IIFS. This led to the establishment in the early nineties of AAOIFI, which developed standards specific to IIFS. ${ }^{63}$ While there has been some progress through using AAOIFI's standards, the accounting pillar of the financial information infrastructure for IIFS continues to present challenges. Wherever IFRS are the only rule, they may not generate financial statements correctly reflecting the IIFS' performance, and may instead give a false sense of reliability. Where AAOIFI standards

\footnotetext{
${ }^{63}$ AAOIFI's standards are mandatory for the following markets: Bahrain, Jordan, Sudan, Qatar, and Dubai International Financial Center. Syria is considering their adoption. The standards are used as guidelines in Saudi Arabia, Kuwait, Malaysia, Lebanon, and Indonesia. Most Islamic banks’ Shariah supervisory committees use AAOIFI standards as guidelines.
} 
prevail, they would enable the accounting system to deal adequately with IIFS specificities. However, they may make cross-sector comparisons difficult.

Table IV - Country Approaches to Accounting and Auditing Standards for IIFS

\begin{tabular}{|c|c|c|}
\hline Country & $\begin{array}{l}\text { AAOIFI standards (adopted } \\
\text { adopted/recommended/ adapted) } \\
\underline{\text { or national IIFS specific standards }}\end{array}$ & Non-IIFS specific standards \\
\hline Bahrain & $\checkmark$ & \\
\hline DIFC & $\checkmark$ & \\
\hline Egypt & & $\checkmark$ \\
\hline Indonesia & $\checkmark$ & \\
\hline Jordan & $\checkmark$ & \\
\hline Lebanon & $\checkmark$ & \\
\hline Malaysia & $\checkmark$ & \\
\hline Philippines & & $\checkmark$ \\
\hline Qatar & $\checkmark$ & \\
\hline Saudi Arabia & $\checkmark *$ & \\
\hline Sudan & $\checkmark$ & \\
\hline Syria & $\checkmark$ & \\
\hline Thailand & & $\checkmark$ \\
\hline Turkey & & $\checkmark$ \\
\hline USA & & $\checkmark$ \\
\hline UK & & $\checkmark$ \\
\hline
\end{tabular}

The provision of financial information on IIFS continues to be limited. Investors and analysts may not be entirely familiar with the nature of IIFS and with AAOIFI standards, but the action of market forces has already brought about substantial progress. For instance, leading international rating agencies now monitor and rate IIFS and are acquainted with AAOIFI prescriptions. ${ }^{64}$ They have also tailored their rating mechanisms to the risk profile of Islamic banks. ${ }^{65}$ However, the absence of a consensus on

\footnotetext{
${ }^{64}$ These are Fitchratings, Capital Intelligence and Moody’s Investors Service. Capital Intelligence was the pioneer in rating and analyzing IIFS. It now covers 21 IIFS across 8 countries.

${ }^{65}$ Capital Intelligence uses the same categories to rate IIFS and ICFS, falling namely in 6 areas: regulation and supervision, operating environment, franchise strength, management quality, financial fundamentals, and external support. However, given the nature of IIFS, the analytical focus is adjusted. For instance, liquidity risk management may be more important in rating IIFS than in rating ICFS given the lack of Shariah-compliant secondary markets.
} 
internationally accepted and standardized accountancy practices for IIFSs reduces the ability to make comparisons across markets, and may reduce consistency in ratings. ${ }^{66}$

Overcoming these financial information challenges should promote a competitive environment for IIFSs, and thereby enhance the contribution that competition can bring to sound IIFS CG. ${ }^{67}$

There are three alternative approaches to empowering and protecting UIA holders. Rights that normally belong to equity-holders could be extended to UIA holders. Or, moving in the opposite direction, UIA holders could be granted full debt-holding status and the protection it carries. Alternatively, the sui generis status of UIA holders could be maintained, provided that specific governance structures for the protection of UIA holders' interests are in place.

The first option would be the extension of shareholders' rights and duties to UIA holders. Given their equity-like investment, it may be argued that UIA holders should be on an equal footing with shareholders and thus be granted the right to have a voice by electing board representatives. This measure would increase their ability to air their demands and concerns with management. It would also satisfy these depositors' demand for greater involvement in the strategic management of the IIFS. ${ }^{68}$

If extending shareholders' rights to UIA holders is deemed impractical, depositors' protection may be an alternative option. However, the moral hazard argument against deposit insurance schemes would need to be addressed. Furthermore, the PLS nature of investment accounts prevents the application of deposit insurance in its present form, and a Shariah-compliant version would need to be developed.

\footnotetext{
${ }^{66}$ For example, as we can see onn table IV, AAOIFI's standards are not broadly endorsed by regulatory agencies.

${ }^{67}$ Grosfeld and Tressel (2001) provide evidence that competition has an important complementary effect where good CG mechanisms are already in place.

${ }^{68}$ In a survey of IIFS consumers' preferences, Chapra and Ahmed (2002) record an interest by depositors to be involved in the strategic management of the bank.
} 
The third option would be to create new governance structures that cater to the specific needs of UIA holders. One possibility is to elect a special representative or body that would act as an intermediary and, if necessary, expose wrongdoings. Such a policy would provide the key rationale for the creation of a permanent institutional channel to facilitate information flows from and to UIA holders. However, the creation of a new agent would bring with it additional agency problems and the risk of multiplying rather than diffusing the asymmetries of information to which UIA holders are subject.

Concerns on potential conflicts of interest should lead regulators to emphasize a transparent conduct of business. In this regard, smoothing of returns to UIA holders as currently practiced appears to be a significant obstacle to transparency. The practice of smoothing of returns introduces a veil of opacity between depositors and the firm, whereas, in all circumstances, an IIFS should be fully transparent in the use of funds. AAOIFI FAS 11 provides clear principles and guidelines on this issue. In particular, it requires IIFSs to disclose the shares of the actual profits and of the funds from the profit equalization reserve in the returns they receive. ${ }^{69}$ In addition, each IIFS needs to adopt clear provisions regulating contributions to these funds and their disclosure in financial statements and annual reports. ${ }^{70}$

Overall, internal and external CG structures can complement each other in strengthening stakeholders' protection. Internally, the protection of minority shareholders and provisions for increased disclosure need attention, but can be addressed by the application of existing rules. The commingling of resources, balancing UIA holders' risks and rights, and the utilization of reserve funds need concrete actions to enhance the soundness of the internal CG frameworks of IIFS.

\footnotetext{
${ }^{69}$ Some IIFS have already established the practice of distinguishing between profit distribution and the amount of reserve distributed.

${ }^{70}$ Decisions pertaining to PER and IIR should ideally be left to the business. However, concerns over maintaining the UIA holder principal and the systemic consequences that losses may provoke have led some regulators to intervene. For instance, the Banking Law of Jordan as amended in 2003 establishes a minimum deduction of $10 \%$ on earnings to be invested in an investment risk fund in order to cover losses in mutual investment accounts. Such minimum deduction may be increased by the CB (Art. 55).
} 
Externally, recognizing the specificity of IIFS within the broader institutional infrastructure, would contribute to greater transparency. Whichever regulatory approach is chosen, it can be guided by two rules of thumb. First, regulators need be flexible and to work with IIFS in order to become acquainted with the needs of the industry and be able to develop acceptable regulatory frameworks. Secondly, private self-regulatory initiatives can provide channels to market discipline and may be as important in Islamic finance as in a conventional financial system. In jurisdictions where regulations result in constraints on Islamic finance, IIFS need to evaluate which licensing status is best suited to their need for protecting stakeholders' interests. Regulatory authorities and market participants ought to become well versed in the nature and implication of the rules adopted, and thus help to promote market discipline without placing an undue burden on the IIFS. The existence of an infrastructure, such as IIFS-adapted accounting and auditing standards, that would permit the production of timely and reliable financial information, would complement the role of public authorities and reputational agents.

\section{Conclusions}

Poor CG can carry heavy financial costs for IIFS' stakeholders, as it would for other corporations. In addition, poor governance in IIFS would undermine their credibility as financial businesses offering services in compliance with Shariah. Given the fledgling nature of the sector and its ethical foundations, the effects of a CG failure could be particularly damaging. While international standards applicable to conventional financial businesses can offer useful inspiration for IIFS CG, their simple extension to IIFS would not be effective in providing safeguards for IIFS stakeholders. The ongoing efforts of national and international bodies to address these issues focus on the existing shareholding corporate structure of IIFS. They generally do not address the issue of the nature of the corporate structure that would be best adapted to the founding principles of Islamic finance, the services it would offer, and the competition it would face. It would seem, however, that no single model of corporate governance is likely to prevail, as the effectiveness of any framework would depend on the socio-economic context and the specific needs of each jurisdiction. 
Confidence in the consistency of business practices with Shariah can emanate from a SSB as is currently the case. The financial competence of SSB members and their independence would need strengthening. The availability of Shariah compatible guiding principles whose interpretation has broad international acceptability can be helpful. An international self-regulatory Shariah financial scholars' association may help to reconcile the requirements for innovations with the need for broad standards. Business confidence would be strengthened through credible expectations of enforceability of contracts. Expost verification of Shariah compliance could be handled by internal review units, and certified by external auditors and reputational agents.

Protecting the interests of UIA holders has developed into one of the main challenges of IIFS CG. Their status of quasi-shareholders, bearing investment risks but not having a voice, has led to a number of arrangements. They include profit equalization reserves, investment risk reserves, special board committees, or special supervisory attention.

Shortcomings in current practices may require a combination of solutions. In particular, the protection of stakeholders' financial priorities calls for attention to the protection mechanisms for "weak voice" stakeholders, including minority shareholders, the position of UIA holders, transparent use of reserves, disclosure of policies and structures, and the soundness of regulatory and broader institutional controls. Strengthened arrangements that would lead to the emergence of reputational agents that can exert market discipline would be most helpful. The synergies between regulation, arrangments at the corporate level and the actions of market reputational agents could help enhance CG soundness. 


\section{References}

AAOIFI (2001). Accounting, Auditing and Governance Standards for Islamic Financial Institutions. (May 2001, The Accounting and Auditing Organization for Islamic Financial Institutions, Bahrain).

AAOIFI (1999). Statement on the Purpose and Calculation of the Capital Adequacy Ratio for Islamic Banks. (March 1999, The Accounting and Auditing Organization for Islamic Financial Institutions, Bahrain).

Abdel Karim, R. A. (1990) "The Independence of Religious and External Auditors: the Case of Islamic Banks", Accounting, Auditing \& Accountability Journal, Vol. 3, No. 3 (March 1990), 34-44.

Accounting Age (9 January 2003) “Thumbs Down For Auditors’ Rotation”.

Adams, R. and Mehran, H. (2003) "Is Corporate Governance Different for Bank Holding Companies?”, FRBNY Economic Policy Review 9, 123-142.

Ahamd, A. (1997) "Structure of Deposits in Selected Islamic Banks", IRTI Research paper No 48 (Islamic Development bank, Jeddah)

Allen, F. and Gale, D. (1997) "Financial Markets, Intermediaries, and Intertemporal Smoothing”, Journal of Political Economy, Vol. 105, No. 3, 523-46.

Al-Jalahma, A.S. (2004) “Corporate Governance and Islamic Banking”, Islamic Finance Weekly, Vol. 1, No.22 (3 February 2004), 6-7

Altunbas, Y., Evans, L., Molyneux, P. (2001) "Bank Ownership and Efficiency”, Journal of Money, Credit and Banking, Vol. 33, No. 4 (Nov. 2001), 926-954

Azéma, J. (2002) «Le Statut Mutualiste Est-il un Frein à la Croissance ? », Revue D’Economie Financière, Vol 0, No.67, 239-248

Bagsiraj, M.I. (2002) "Islamic Financial Institutions of India: their Nature, Problems and Prospects”, in Iqbal, M. and Llewellyn, D.T. (eds.) Islamic Banking and Finance: New Perspectives on Profit-Sharing and Risk (Edward Elgar Publishing, Northampton, MA, USA, 2002)

Bahrain Monetary Agency (2002). Islamic Banking and Finance in the Kingdom of Bahrain. (Bahrain Monetary Agency, Bahrain)

Ball, I. (2004) "Enhancing Transparency and market Discipline in the Islamic Financial Services Industry” (New York, International Federation of Accountants, May 18, 2004) 
Banaga, A., Ray G. H., and Tomkins, R.T (1994) Audit and Corporate Governance in Islamic Banks: A Joint Practitioner-Academic Research Study (Avebury, Brookfield, VT, USA)

BCBS (1999) “Enhancing Corporate Governance for Banking Organizations” (Basel Committee on banking Supervision, Basel, Switzerland)

BCBS (2002) "Internal Audit and the Supervisor's Relationship with Auditors: a Survey” (Basel Committee on banking Supervision, Basel, Switzerland)

Berglöf, E. and Claessens S. (2004) "Enforcement and Corporate Governance”, World Bank Working Paper No. 3409 (Washington, World Bank, September 17, 2004)

Berle, A. A. and Means, G. (1932) The Modern Corporation and Private Property (New York, Macmillan);

Black, H. and Dugger, R.H (1981) “Credit Union Structure, Growth and Regulatory Problems”, The Journal Of Finance, Vol. 36, No. 2 (May 1981), 529-538

Boatright, J. R. (2002) "Contractors as Stakeholders: reconciling Stakeholder theory with the Nexus-of-Contracts Firm”, Journal of Banking and Finance, Vol. 26, 1837-1852

Bossone, B. and Promisel, L. (1998) "Strengthening Financial Systems in Developing Countries: the Case fro Incentives-Based Financial Sector Reforms”, in Responding to the Global Financial Crisis, Background Papers/Program of Seminars, 1998 Annual Meetings of the International Monetary Fund and the World Bank Group (Washington, World Bank)

Briston, R. and Al-Ashker, A. (1986) “Religious Audit: Could it Happen Here?”, Accountancy, Vol.98, No. 1118, October 1986, 120-121.

Caprio, G., Laeven, L. And Levine, R. (2004) “Governance and Bank Valuation”, Policy Research Working Paper 3202 (Washington, World Bank, February 2004)

Caprio, G., and Levine, R. (2002), “Corporate Governance of Banks: Concepts and International Observations”, paper presented in the Global Corporate Governance Forum Research Network Meeting, April 5. 2002

Central Bank of Jordan (2003) "Bank Directors' Handbook of Corporate Governance” (Central bank of Jordan, Jordan) http://uploads.batelco.jo/cbj/uploads/corp_e.pdf

Chapra, M. and Ahmed, H. (2002) "Corporate Governance in Islamic Financial Institutions” Occasional Paper No. 6 (Islamic Research and Training Institute: Islamic Development Bank, Jeddah) 
Chapra U. and T. Khan (2000). Regulation and Supervision of Islamic Banks". Occasional Paper No. 3. (Islamic Research and Training Institute: Islamic Development Bank, Jeddah)

Claessens, S. (2003) "Corporate Governance and Development" (October 2003). http://ssrn.com/abstract=642721

Cornforth, C. (2004) "The Governance of Cooperatives and Mutual Association: a Paradox Perspective", Annals of Public and Cooperative Economics, Vol. 75, No. 1, 1132

Dalmaz, S. (2002) «Les Banques Coopératives Européennes: Bilan et Perspectives», Revue D’Economie Financière, Vol 0, No.67, 73-84

Davis, K. (1994) "Prudential Regulations and Australian Credit Unions", Australian Journal of Management Vol. 19, No. 1 (June 1994), 31-46

Demirgüç-Kunt, A., Detragiache, E. (2002) "Does Deposit Insurance Increase Banking System Stability? An Empirical Investigation” Journal of Monetary Economics, Vol. 49, No. 7, 1373-1406

Dewatripont M. and Tirole, J. (1993) "Efficient Governance Structure: Implications for Banking Regulations”, in Mayer, C. and Vives, X. (eds.) Capital Markets and Financial Intermediation (New York, USA, Cambridge University Press, 1993)

Di Salvo, R. (2002) «La Governance des Systèmes Bancaires Mutualistes et Coopératifs en Europe, Revue D'Economie Financière, Vol 0, No.67, 165-180

El-Hawary, D., Grais, W. and Iqbal, Z. (2004): "Regulating Islamic Financial Institutions: the Nature of the Regulated, Policy Research Working Paper 3227 (Washington, World Bank, March 2004)

Errico, L. and M. Farrahbaksh (1998). "Islamic Banking: Issues in Prudential Regulation and Supervision”. IMF working paper, IMF/98/30. (Washington: International Monetary Fund, March, 1998).

Fama E.F. (1980) "Agency problems and the Theory of the Firm” The Journal of Political Economy, Vol. 88, No. 2 (April 1980), 228-307

Fama, E.F. and Jensen, M.C. (1983a) "Agency Problems and Residual Claims”, The Journal of Law and Economics, Vol. 26, No. 2 (June 1983), 327-350

Fama, E.F. and Jensen, M.C. (1983b) "Separation of Ownership and Control", The Journal of Law and Economics, Vol. 26, No. 2 (June 1983), 301-326 
Ferri, G., Masciandaro, D. and Messori, M. (2001) "Governo Societario ed Efficienza delle Banche Locali di Fronte all'Unificazione dei Mercati Finanziari”, in P. Alessandrini (eds.) Il Sistema Finanziario Italiano tra Globalizzazione e Localismo, il Mulino, Bologna, 163-89.

FEE (2004) "Mandatory Rotation of Audit Firms" (Study by the FEE, Fédération des Experts Comptables Européens, October 2004)

Fischer, K. P. (1998) "Financial Cooperatives: A "Market Solution" to SME and Rural Financing”, CREFA Working Paper 98-03, http://ssrn.com/abstract=73990

Fremond, O. and Capaul, M. (2002) "The State of Corporate Governance: Experience from Country Assessments” World Bank Policy Research Working Paper 2858 (Washington, World Bank, June 2002)

Gueslin, A. (2002) «Les Banques de l'Economie Sociale en France: Perspectives Historiques », Revue D’Economie Financière, Vol 0, No.67, 21-44

Gorton, G., and Schmid, F. (1999) "Corporate Governance, Ownership Dispersion and Efficiency: Empirical Evidence from Austrian Cooperative Banks”, Journal of Corporate Finance, Vol.5, No. 2,119-140

Grais, W and Pellegrini M. (2006b) “Corporate Governance and Stakeholders' Financial Interests in Institutions Offering Islamic Financial Services, September, World Bank.

Grais, W and Pellegrini M. (2006c) "Corporate Governance and Shariah Compliance in Institutions Offering Islamic Financial Services, September, World Bank.

Grosfeld, I. and Tressel, T. (2001) "Competition and Corporate Governance: Substitutes or Complements? Evidence from the Warsaw Stock Exchange”, DELTA Working Papers 2001-06, DELTA (Ecole Normale Supérieure).

Gurtner, E., Jaeger, M. and Ory, J. (2002) «Le Statut de Coopérative Est-il Source d'Efficacité dans le Secteur Bancaire, Revue D’Economie Financière, Vol 0, No.67, 133-164

Hart, O. and Moore, J. (1996) “The Governance of Exchanges: Members' Cooperatives versus Outside Ownership”, Oxford Review of Economic Policy, Vol. 12, No. 4, 53-69

Hirschman, A.O. (1970) Exit Voice and Loyalty: Responses to Decline in Firms, Organizations and States (Harvard University Press, Cambridge, Massachusetts, USA

Hirschman, A.O. and Nelson, R.R (1976) "Some Uses of the Exit-Voice Approach", The American Economic Review, Vol. 66, No.2 (May 1976), 386-391 
IOSCO (2004) "Islamic Capital Market Fact Finding Report - Report of the Islamic Capital market Task Force of the International Organization of Securities Commissions" (July 2004)

Iqbal, Zamir and Abbas Mirakhor (2004), "Stakeholders Model of Governance in Islamic Economic System", Islamic Economic Studies, Vol. 11, No.2 (March 2004), 43-63

Islamic Banker (2002) "Creating Best Practice in Shariah Advisory”, Issue No.78, July 2002

Islamic Banker (2003) "Should Shariah Advisories Be Regulated”, Issue No. 84, January 2003

Jensen, M.C. (1986) "The Takeover Controversy: Analysis and Evidence", Midland Corporate Finance Journal, 4, 6-32

Jensen, M.C. and Meckling, W.H. (1976) "Theory of the Firm: Managerial Behavior, Agency Costs and Ownership Structure”, Journal of Financial Economics, Vol. 3, No. 4 (October 1976), 305-360

Kay, J. (1991) "The economics of Mutuality", Annals of Public and Cooperative Economics, Vol. 62, No. 3, 309-318

Khan, M. F. and Feddad (2004) "The Growth of Islamic Financial Industry: Need for Setting Standards for Shariah Application”, paper presented at the Sixth Harvard Forum on Islamic Finance, May 2004

Khan, M. Y. (2001) "Banking Regulations and Islamic Banks in India: Status and Issues”, International Journal of Islamic Financial Services, Vol. 2, No. 4 (January-March 2001), http://islamic-finance.net/journals/journal8/mykhan.pdf

Khan, T. and Ahmed, H (2001), "Risk Management: An Analysis of Issues in Islamic Financial Industry”, Occasional Paper No. 5 (Islamic Research and Training Institute: Islamic Development Bank, Jeddah)

Kini, O., Kracaw, W. and Mian, S. (2004) "The Nature of Discipline by Corporate Takeovers”, The Journal of Finance, Vol. 59, No. 4 (August 2004), 1511-1552

Kotz, H, H. and Nagel, J. (2002) «Banques Mutualistes et Systèmes Financiers : une Analyse Comparative Allemagne, Grande-Bretagne, France», Revue D’Economie Financière, Vol 0, No.67, 57-72

Levine, R. (2004) "The Corporate Governance of Banks: A Concise Discussion of Concepts and Evidence," Policy Research Working Paper Series 3404 (The World Bank, Washington, DC) 
Macey, J.R. and O'Hara, M. (2003) “The Corporate Governance of Banks”, FRBNY Economic Policy Review 9, No. 1 (April), 91-107

Morgan, D. P. (2002) "Rating Banks: Risk and Uncertainty in an Opaque Industry," American Economic Review Vol. 92, No. 4, 874-888.

Nooteboom, B. (1999) "Voice- and Exit-Based Forms of Corporate Control: AngloAmerican, European and Japanese”, Journal of Economic Issues, Vol. 33, No. 4 (December 1999), 845-860

OECD (2004) "OECD Principles of Corporate Governance" (The Organization for Economic Cooperation and Development, Paris, France)

Patin, R.P. Jr. and McNiel, D.W. (1991a) "Member Group Orientation of Credit Unions and Total Member Benefits, Review of Social Economy, Vol. 49, No. 1 (Spring 1991), 39-61.

Patin, R.P. Jr. and McNiel, D.W. (1991b) "Benefit Imbalances among Credit Union Member Groups: Evidence of Borrower-dominated, Saver-dominated and Neutral Behaviour” Applied Economics, Vol. 23, No. 4B (April 1991), 769-780.

Prowse, S. (1998) "Corporate Governance: Emerging Issues and Lessons from East Asia", in Responding to the Global Financial Crisis, Background Papers/Program of Seminars, 1998 Annual Meetings of the International Monetary Fund and the World Bank Group (Washington, World Bank)

Prowse, S. (1997) "The Corporate Governance System in Banking: What Do We Know? Banca del Lavoro Quarterly Review (March), 11-40.

Ramesha, K (2003) "Cooperative Banking and Financial Sector Reforms in India: an Agenda for Future Research", paper presented at the International Conference on Mapping Co-operative Studies in the New Millennium, May 28-31, 2003,Victoria BC, Canada.

Richards, D. A. (2002) "Internal and External Auditors - Inside and Out", www.theiia.org/ecm/print.cfm?doc id=3648

Sarbanes-Oxley Act of 2002, Public Law 107-204, USA, July 30, 2002. http://news.findlaw.com/hdocs/docs/gwbush/sarbanesoxley072302.pdf

Sarker, A. A. (1999) "Islamic Business Contracts, Agency Problem and the Theory of the Islamic Firm”, International Journal of Islamic Financial Services, Vol. 1, No. 2

Shleifer, A. and Vishny, R W. (1996) "A Survey of Corporate Governance", NBER Working Paper No. W5554 (April 1996). http://ssrn.com/abstract=10182 
Shahul, H. et al. (2004) "Alternative Disclosure and Performance Measures for Islamic Banks”, International Islamic University of Malaysia.

Smith, D.J. (1984) "A Theoretic Framework for the Analysis of Credit Union Decision Making” The Journal Of Finance, Vol. 39, No. 4 (September 1984), 1155-1168

Smith, D.J., Cargill T.F. and Meyer R.A. (1981): “An Economic Theory of a Credit Union”, The Journal Of Finance, Vol. 36, No. 2 (May 1981), 519-528

Spear, R. (2004) "Governance in Democratic Member-Based Organizations, Annals of Public and Cooperative Economics, Vol. 75, No. 1, 33-59

Starr, M. and Yilmaz, R. (2004) "Bank Runs in Emerging-Market Economies: Evidence from Turkey's Special Finance Houses”, presented at the 2005 ASSA meetings, Philadelphia, January 7-9, 2005

Summer, M. (1998) "Does Mandatory Rotation Enhance Auditor Independence", Zeitschrift für Wirtschafts- und Sozialwissenschaften, Vol. 118, No. 3 (1998), 327-359

Tirole, J. (1999) “Corporate Governance”, CEPR Discussion Paper No. 2086 (London, Centre for Economic Policy Research) http://www.cepr.org/pubs/dps/DP2086.asp

Toporowski, J. (2002) «La Banque Mutuelle : de l’Utopie au Marché des Capitaux - Le Cas Britannique, Revue D’Economie Financière, Vol 0, No.67, 45-56

Whalen, C. (2003) "Revisiting Sarbanes-Oxley: Was the Well-Intentioned Landmark Legislation Slapped Together Too Quickly?”, International Economy, Vol. 17, No. 4 (Fall 2003), 40-43

World Bank (2004) "Cooperative Financial Institutions and Access to Finance" Proceedings of the Workshop held on March 4, 2004, (Washington, DC World Bank)

Zaher, T. and K. Hassan (2001). "A Comparative Literature Survey of Islamic finance and Banking". Financial Markets, Institutions and Instruments, Vol. 10, No.4, November 200, 155-199. 


\section{Annex I: Glossary of Arabic Terms}

\begin{tabular}{|c|c|}
\hline $\begin{array}{l}\text { Amana } \\
\text { (Demand deposits) }\end{array}$ & $\begin{array}{l}\text { Deposits held at the bank for safekeeping purpose. They are guaranteed in capital value } \\
\text { and earn no return. }\end{array}$ \\
\hline Fatwa & Legal opinion issued by a qualified scholar on matters of religious belief and practice. \\
\hline $\begin{array}{l}\text { Fiqh } \\
\text { (Islamic jurisprudence) }\end{array}$ & $\begin{array}{l}\text { It refers to Islamic jurisprudence that covers all aspects of life: religious, political, social } \\
\text { and economic. Fiqh is mainly based on interpretations of the Qur'an and Sunna (sayings } \\
\text { and deeds of the prophet). }\end{array}$ \\
\hline Fiqh al-Muamalat & Islamic Commercial Jurisprudence. \\
\hline Gharar & $\begin{array}{l}\text { Literally, : uncertainty, hazard, chance or risk. Technically, sale of a thing which is not } \\
\text { present at hand; or the sale of a thing whose consequence or outcome is not known; or a } \\
\text { sale involving risk or hazard in which one does not know whether it will come to be or } \\
\text { not, such as fish in water or a bird in the air. }\end{array}$ \\
\hline Halal & That which is permissible according to Shariah Law. \\
\hline Haram & $\begin{array}{l}\text { Unlawful according to the Shariah. It indicates transactions which are not permissible } \\
\text { under Islamic law. }\end{array}$ \\
\hline Hibah & Literally gift. A gift awarded voluntarily in return for a loan. \\
\hline $\begin{array}{l}\text { Ju'ala } \\
\text { (Service charge) }\end{array}$ & $\begin{array}{l}\text { A party pays another a specified amount of money as a fee for rendering a specific } \\
\text { service in accordance to the terms of the contract stipulated between the two parties. This } \\
\text { mode usually applies to transactions such as consultations and professional services, } \\
\text { fund placements and trust services. }\end{array}$ \\
\hline Kifala & $\begin{array}{l}\text { It is a pledge given to a creditor that the debtor will pay the debt, fine, or liability. A third } \\
\text { party becomes surety for the payment of the debt if unpaid by the person originally } \\
\text { liable. }\end{array}$ \\
\hline $\begin{array}{l}\text { Mudaraba } \\
\text { (Trustee finance contract) }\end{array}$ & $\begin{array}{l}\text { Rabb -al- mal (capital's owner) provides the entire capital needed to finance a project } \\
\text { while the entrepreneur offers his labor and expertise. Profits are shared between them at } \\
\text { a certain fixed ratio, whereas financial losses are exclusively borne by rabb-al-mal. The } \\
\text { liability of the entrepreneur is limited only to his time and effort. }\end{array}$ \\
\hline $\begin{array}{l}\text { Murabaha } \\
\text { (Mark-up financing) }\end{array}$ & $\begin{array}{l}\text { The seller informs the buyer of his cost of acquiring or producing a specified product. } \\
\text { The profit margin is then negotiated between them. The total cost is usually paid in } \\
\text { installments. }\end{array}$ \\
\hline $\begin{array}{l}\text { Musharaka } \\
\text { (Equity participation) }\end{array}$ & $\begin{array}{l}\text { The bank enters into an equity partnership agreement with one or more partners to jointly } \\
\text { finance an investment project. Profits (and losses) are shared strictly in relation to the } \\
\text { respective capital contributions. }\end{array}$ \\
\hline $\begin{array}{l}\text { Qard Hassan } \\
\text { (Beneficence loans) }\end{array}$ & $\begin{array}{l}\text { These are zero-return loans that the Qur'an encourages Muslims to make to the needy. } \\
\text { Banks are allowed to charge borrowers a service fee to cover the administrative expenses } \\
\text { of handling the loan. The fee should not be related to the loan amount or maturity. }\end{array}$ \\
\hline Quran & Islamic scriptures believed by Muslims to be God's revelation to the Prophet. \\
\hline Riba’' & $\begin{array}{l}\text { Literally, an excess or increase. Technically, an increase, which in a loan transaction or } \\
\text { in exchange of a commodity, accrues to the owner (lender) without giving an equivalent } \\
\text { counter value or recompense in return to the other party. }\end{array}$ \\
\hline $\begin{array}{l}\text { Shariah } \\
\text { (Islamic Law) }\end{array}$ & $\begin{array}{l}\text { The Islamic Law extracted from the Qur'an and Sunna (sayings and deeds of the } \\
\text { Prophet). }\end{array}$ \\
\hline Sunna & Deeds of the Prophet. \\
\hline Takaful & $\begin{array}{l}\text { Arabic name for insurance based on Shariah rules. An Islamic Insurance is a collective } \\
\text { protection scheme. It literally means solidarity. Takaful reflects solidarity and is akin to } \\
\text { mutual insurance. }\end{array}$ \\
\hline Umma & Community of the faithful within Islam \\
\hline Wadiah & A safe custody contract between the depositor (customer) and the custodian (bank). \\
\hline Wikala & $\begin{array}{l}\text { An Agency contract which may include in its terms a fee for the agent. Same contract } \\
\text { can also be used to give a power of attorney to someone to represent another's interests. }\end{array}$ \\
\hline Zakat & Religious tax to be deducted from wealth to be paid to the needy. \\
\hline
\end{tabular}




\section{Annex II: Mission statements of IIFS and ICFS}

\begin{tabular}{|c|c|c|c|}
\hline$\underline{\text { IIFS }}$ & Mission statements, objectives or vision & $\underline{\text { ICFS }}$ & Mission statements, objectives or vision \\
\hline $\begin{array}{l}\text { Jordan Islamic Bank, } \\
\text { Jordan }\end{array}$ & $\begin{array}{l}\text { (The bank's goals are) commitment to providing banking } \\
\text { services based on compliance with the rules and principles of } \\
\text { the glorious Islamic Shariah in all our activities to serve our } \\
\text { community as a whole, and commitment to equally serve the } \\
\text { interests of all related parties including shareholders, } \\
\text { depositors, and employees. (website) }\end{array}$ & $\begin{array}{l}\text { Mizuho Financial } \\
\text { Group, Japan }\end{array}$ & $\begin{array}{l}\text { (Our) (...) basic principles of the consolidation are: } 1 \text { ) offer } \\
\text { a wide range of the highest quality financial services to our } \\
\text { customers 2) maximize shareholders' value and, as the } \\
\text { leader of Japan's financial services industry, earn the trust of } \\
\text { society at large, 3) offer attractive and rewarding job } \\
\text { opportunities for employees (...) }\end{array}$ \\
\hline $\begin{array}{l}\text { Bank Islam Malaysia } \\
\text { Berhad }\end{array}$ & $\begin{array}{l}\text { The Corporate Mission of the Bank is to seek to operate as a } \\
\text { commercial bank functioning on the basis of Islamic } \\
\text { principles, providing banking facilities and services to } \\
\text { Muslims and the whole population of this country, with } \\
\text { viability and capability to sustain itself and grow in the } \\
\text { process } \\
\text { (The Bank's) Corporate Objective is to provide its customers } \\
\text { with Islamic Banking facilities and services of the highest } \\
\text { possible quality; to attain viability and sufficient level of } \\
\text { profitability to sustain growth; to develop and foster a } \\
\text { competent and innovative management imbibed with high } \\
\text { standards of integrity and Islamic banking professionalism; to } \\
\text { develop a motivated workforce inculcated with appropriate } \\
\text { work ethics fully committed to the Bank and to offer efficient } \\
\text { and courteous service to customers; to constantly strive to } \\
\text { protect its shareholders' interest; to be always conscious of its } \\
\text { responsibilities and duties as an Islamic corporate citizen. }\end{array}$ & $\begin{array}{l}\text { Norges Bank, } \\
\text { Norway }\end{array}$ & $\begin{array}{l}\text { The company's primary objective must be to maximize } \\
\text { shareholders' long-term returns. There must be a clearly } \\
\text { defined business strategy that is anchored in the board of } \\
\text { directors. The company must present accurate, adequate and } \\
\text { timely information concerning its financial position and } \\
\text { other relevant information. } \\
\text { The company's board of directors shall protect the interests } \\
\text { of all shareholders and shall be accountable for the decisions } \\
\text { made by the board. The board of directors shall supervise } \\
\text { the day-to-day management and company activities, and } \\
\text { shall ensure a proper organization of these activities, } \\
\text { including adequate internal control systems. }\end{array}$ \\
\hline $\begin{array}{l}\text { Kuwait Finance House, } \\
\text { Kuwait }\end{array}$ & $\begin{array}{l}\text { In accordance with the Islamic principles, KFH ensures that } \\
\text { while working with the public professionally, the company } \\
\text { guarantees an honorable relationship with its client base and } \\
\text { the Muslim community as a whole }\end{array}$ & $\begin{array}{l}\text { Coastal Federal } \\
\text { Bank, USA }\end{array}$ & $\begin{array}{l}\text { Our basic corporate objective (is) maximizing the value of } \\
\text { our shareholders' investment }\end{array}$ \\
\hline $\begin{array}{l}\text { Faisal Islamic Bank of } \\
\text { Egypt }\end{array}$ & $\begin{array}{l}\text { The ultimate goal being to eventually institute an elaborate } \\
\text { and comprehensive banking system based on the rules of } \\
\text { Islamic Shari'ah which meets the needs of all those } \\
\text { concerned... shareholders-clients-employees. }\end{array}$ & $\begin{array}{l}\text { Deutsche Bank, } \\
\text { Germany }\end{array}$ & $\begin{array}{l}\text { Mission: We compete to be the leading global provider of } \\
\text { financial solutions for demanding clients creating } \\
\text { exceptional value for our shareholders and people. }\end{array}$ \\
\hline
\end{tabular}




\begin{tabular}{|c|c|c|c|}
\hline $\begin{array}{l}\text { Bank Muamalat } \\
\text { Berhad, Malaysia }\end{array}$ & $\begin{array}{l}\text { To build the bank into a modern, dynamic and strong Islamic } \\
\text { Bank that would play a role in providing a viable alternative } \\
\text { to the conventional system, that will contribute to the } \\
\text { development of Modern Malaysia. }\end{array}$ & $\begin{array}{l}\text { Commonwealth } \\
\text { Bank, Australia }\end{array}$ & $\begin{array}{l}\text { The key financial objective of the Bank is to have Total } \\
\text { Shareholder Return in the top quartile of our Australian } \\
\text { listed peers over each rolling five year period. }\end{array}$ \\
\hline $\begin{array}{l}\text { Badr-Forte bank, } \\
\text { Russia }\end{array}$ & $\begin{array}{l}\text { To contribute to the globalization of Islamic Banking as the } \\
\text { principal institution within the Russian Federation } \\
\text { implementing Islamic financial and economic concepts, which } \\
\text { offer a unique solution for social justice and harmony in our } \\
\text { contemporary society }\end{array}$ & $\begin{array}{l}\text { BBVA Group, } \\
\text { Spain }\end{array}$ & $\begin{array}{l}\text { The seven corporate principles are as follows: Focus on the } \\
\text { customer as the centre of business; creation of shareholder } \\
\text { value through business activity; teamwork as the engine in } \\
\text { the creation of value; a management style that generates } \\
\text { enthusiasm; ethical behavior and personal integrity as a way } \\
\text { of understanding and conducting business; innovation as the } \\
\text { engine of progress; and corporate social responsibility as an } \\
\text { intrinsic part of development. }\end{array}$ \\
\hline $\begin{array}{l}\text { AlBaraka Islamic Bank, } \\
\text { (Bahrain and Pakistan) }\end{array}$ & $\begin{array}{l}\text { We strive to be a premier regional Islamic bank, dedicated to } \\
\text { the economic and social development of our target markets, } \\
\text { maximizing our clients and shareholders value, and focusing } \\
\text { on the human resource development in an environment of } \\
\text { creativity and innovation. Albaraka is committed to develop } \\
\text { and promote an integrated Islamic Financial System. } \\
\text { Compliance with the rules and principles of Islamic Sharia is } \\
\text { the core of the banking and financial activities of the Bank. To } \\
\text { this end, the Bank has successfully sought the advice and } \\
\text { expertise of Islamic scholars acclaimed for their knowledge } \\
\text { and piety from all over the Islamic world to guide is path and } \\
\text { monitor its performance (website) }\end{array}$ & $\begin{array}{l}\text { BNP Paribas, } \\
\text { France }\end{array}$ & $\begin{array}{l}\text { BNP Paribas founds its corporate project on three } \\
\text { commitments: 1) toward its customers, BNP Paribas } \\
\text { undertakes to give first priority to their satisfaction and to } \\
\text { constantly improving the quality of their welcome and of the } \\
\text { services offered, 2) toward its shareholders, BNP Paribas } \\
\text { undertakes to put value creation at the very heart of its } \\
\text { options, 3) toward its employees, BNP Paribas undertakes to } \\
\text { ensure a dynamic and stimulating management of careers } \\
\text { and remuneration by developing employee share-ownership } \\
\text { and promoting social dialogue. } \\
\text { The respect of these commitments is guaranteed by the team } \\
\text { spirit of all the bank's employees and their adherence to a } \\
\text { code of ethics founded on transparency, professionalism and } \\
\text { quality }\end{array}$ \\
\hline $\begin{array}{l}\text { Dubai Islamic Bank, } \\
\text { UAE }\end{array}$ & $\begin{array}{l}\text { (The) Objectives of the Bank (are): 1) Providing banking } \\
\text { services of the highest standards according to Islamic Shariah } \\
\text { without dealing in riba (interest on money) and by using the- } \\
\text { state-of-the-art technology in computer, telecommunication } \\
\text { and information system 2) Investing funds prudently to } \\
\text { achieve optimum and not maximum profits, for the mutual } \\
\text { benefit of customers and the bank. 3) Coordination, } \\
\text { cooperation and integration with other financial bodies that } \\
\text { apply Islamic Shariah in their dealings, in order to support } \\
\text { creating a base and regulations for an Islamic financial } \\
\text { system. 3) Development of the Islamic society in all fields of } \\
\text { the economy by investing in industries, agriculture, } \\
\text { commerce, and real estate in order provide job opportunities. }\end{array}$ & $\begin{array}{l}\text { Jyske Bank A/S, } \\
\text { Denmark }\end{array}$ & $\begin{array}{l}\text { (...) The Jyske Bank Group is managed and operated as a } \\
\text { business. At the same time, we attach great importance to } \\
\text { treating the three groups of stakeholders - shareholders, } \\
\text { customers and employees - with equal respect. (...) } \\
\text { Our objective is to provide our shareholders with a } \\
\text { satisfactory long-term return on their investment. Thus, the } \\
\text { aim is for Jyske Bank every year to be one of the top- } \\
\text { performing Danish banks based on the level of our earnings. } \\
\text { Jyske Bank is thus an excellent choice for shareholders who } \\
\text { want to make a long-term investment and who do not attach } \\
\text { great importance to decisions which generate only short- } \\
\text { term price increases. }\end{array}$ \\
\hline
\end{tabular}




\begin{tabular}{|c|c|c|c|}
\hline & $\begin{array}{l}\text { 4) Promotion of social benevolence through its Islamic } \\
\text { methods, particularly through Zakat. 5) Contributing to the } \\
\text { welfare of society in line with the five main tenets of Islam, } \\
\text { namely protection of life, purity of mind, property, honour and } \\
\text { social justice. 6) Promoting the savings habit and encouraging } \\
\text { people to invest wisely within the parameters of Islamic } \\
\text { Shariah through investment and finance instruments to suit } \\
\text { individual requirements. 7) Making available the necessary } \\
\text { capital for entrepreneurs for the establishment of economic } \\
\text { projects and creation of alternative instruments for finance } \\
\text { according to Islamic Shariah. }\end{array}$ & & \\
\hline $\begin{array}{l}\text { Islamic Bank of } \\
\text { Thailand, Thailand }\end{array}$ & $\begin{array}{l}\text { (The bank's goals are): to maintain the role of a bank that is } \\
\text { not tied up with interest; to strengthen the business; to carry } \\
\text { out social and organizational stability; to provide an excellent } \\
\text { service; and to well direct and supervise the community } \\
\text { development }\end{array}$ & $\begin{array}{l}\text { RHB Group, } \\
\text { Malaysia }\end{array}$ & $\begin{array}{l}\text { Mission: To become the most admired Malaysian financial } \\
\text { services company by providing excellent customer services, } \\
\text { enhancing shareholder value, providing challenging career } \\
\text { and learning opportunities for employees, demonstrating } \\
\text { responsibility for society. }\end{array}$ \\
\hline $\begin{array}{l}\text { ABC Islamic Bank } \\
\text { (E.C.) }\end{array}$ & $\begin{array}{l}\text { Our mission is to uphold our carefully formulated Islamic } \\
\text { principles in the quest for mutual prosperity for our clients } \\
\text { and the Bank. In pursuit of our mission, we commit the Bank } \\
\text { to the purest forms of Islamic banking products and services } \\
\text { from a Shari'a perspective. We remain demonstrably } \\
\text { independent from the conventional sector and recognize the } \\
\text { importance of Islam's social objectives in conducting } \\
\text { business. We are committed to delivering a level of service } \\
\text { that matches, or exceeds, the market practice internationally. } \\
\text { To do so, we seek to employ the best available human } \\
\text { resources and the technology to apply the highest } \\
\text { professional, moral and ethical standards. }\end{array}$ & $\begin{array}{l}\text { HSBC Canada, } \\
\text { Canada }\end{array}$ & $\begin{array}{l}\text { HSBC in Canada is committed to being Canada's leading } \\
\text { international financial services organization, a leader in } \\
\text { chosen markets, and recognized by its clients as proactive, } \\
\text { responsive, competitive and secure. To achieve a superior } \\
\text { long term return for our shareholder we will efficiently } \\
\text { deliver a differentiated client experience which reflects our } \\
\text { commitment to excellence in sales, service and products, and } \\
\text { which is delivered by highly motivated and well qualified } \\
\text { employees, working as a team. Through managing for value, } \\
\text { HSBC in Canada is committed to making a world of } \\
\text { difference to its clients, employees, communities and } \\
\text { shareholders }\end{array}$ \\
\hline $\begin{array}{l}\text { Meezan Bank Limited, } \\
\text { Pakistan }\end{array}$ & $\begin{array}{l}\text { Establish Islamic banking as banking of first choice to } \\
\text { facilitate the implementation of an equitable economic system, } \\
\text { providing a strong foundation for establishing a fair and just } \\
\text { society for mankind. To be a premier Islamic bank, offering a } \\
\text { one-stop shop for innovative value added products and } \\
\text { services to our customers within the bounds of Shariah, while } \\
\text { optimizing the stakeholders' value through an organizational } \\
\text { culture } \\
\text { based on learning, fairness, respect for individual enterprise } \\
\text { and performance.(website) }\end{array}$ & $\begin{array}{l}\text { Barclays Group, } \\
\text { UK }\end{array}$ & $\begin{array}{l}\text { Barclays aims to be one of the most admired financial } \\
\text { services organizations in the world; in the eyes of our } \\
\text { shareholders, our customers, our colleagues and the } \\
\text { communities in which we work. } \\
\text { The best measure of our long term performance is the total } \\
\text { return we give to our shareholders - the increase in the price } \\
\text { of our shares, assuming that any dividends are used to buy } \\
\text { more shares, known as 'Total Shareholder Return'. }\end{array}$ \\
\hline
\end{tabular}




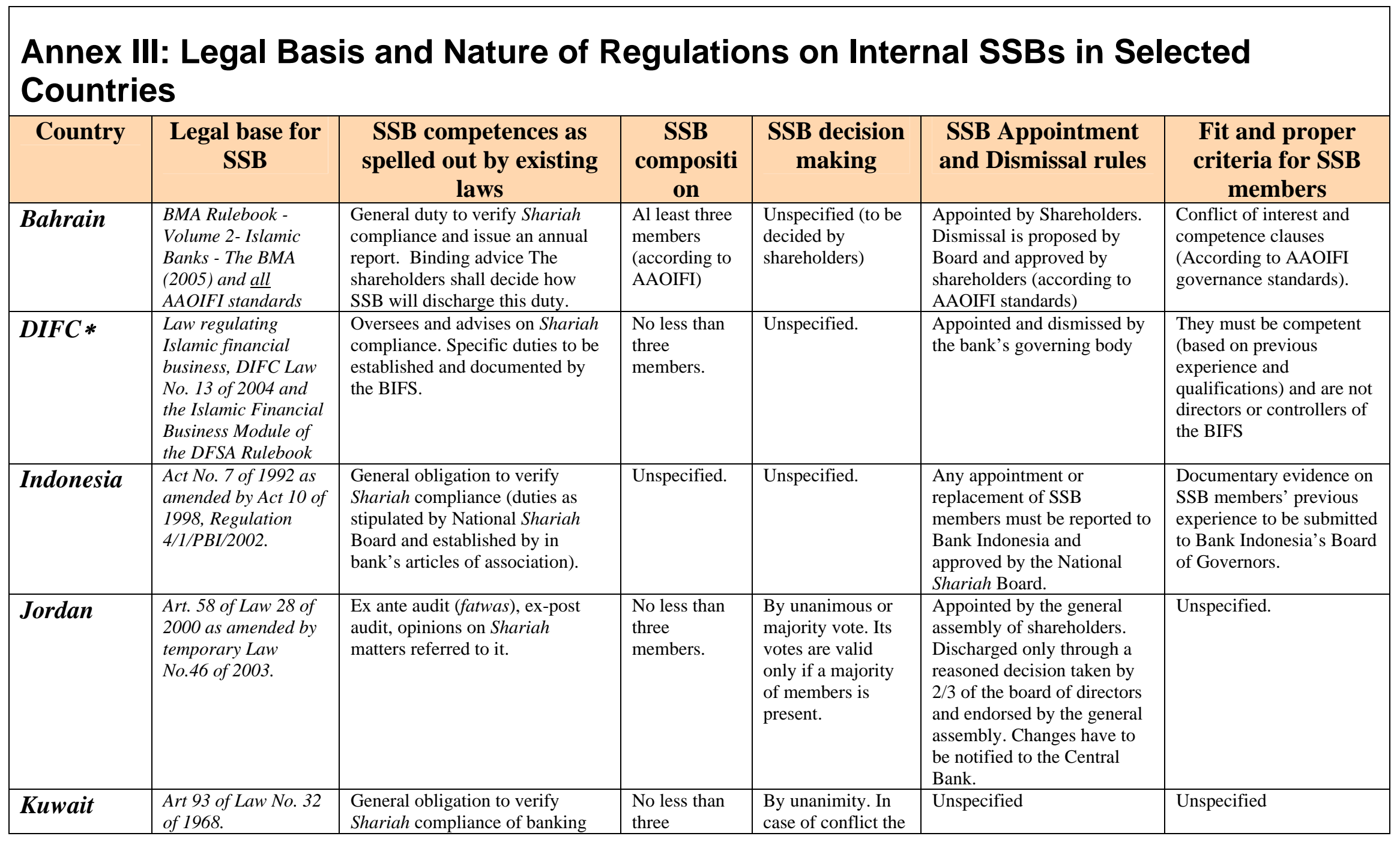




\begin{tabular}{|c|c|c|c|c|c|c|}
\hline & & operations. & members. & $\begin{array}{l}\text { matter is referred } \\
\text { to the Fatwa } \\
\text { Board. }\end{array}$ & & \\
\hline Lebanon & $\begin{array}{l}\text { Law No. } 575 \text { on } \\
\text { "Establishing Islamic } \\
\text { Banks in Lebanon". }\end{array}$ & $\begin{array}{l}\text { Certification of Shariah } \\
\text { compliance and proposals for } \\
\text { properly achieving bank's } \\
\text { objectives pursuant to the } \\
\text { Shariah. }\end{array}$ & $\begin{array}{l}\text { Three } \\
\text { members. }\end{array}$ & Unspecified. & $\begin{array}{l}\text { Appointment for a renewable } \\
\text { three- year period. }\end{array}$ & $\begin{array}{l}\text { Unspecified (experts' } \\
\text { background must be in } \\
\text { Islamic law, doctrine and } \\
\text { banking and financial } \\
\text { operations). }\end{array}$ \\
\hline Malaysia & $\begin{array}{l}\text { Islamic Banking Act } \\
\text { of } 1983 \text { and Central } \\
\text { Bank of Malaysia Act } \\
1958 \text { (Revised 1994) } \\
\text { and Guidelines on } \\
\text { the Governance of } \\
\text { Shariah Committees } \\
\text { (2004) }\end{array}$ & $\begin{array}{l}\text { Binding advice Shariah on } \\
\text { compliance of banking operations } \\
\text { for Islamic Banks. The Central } \\
\text { Shariah Advisory Council is the } \\
\text { ultimate arbiter. }\end{array}$ & Unspecified. & Unspecified. & Unspecified. & $\begin{array}{l}\text { There are several } \\
\text { incompatibility clauses. }\end{array}$ \\
\hline Pakistan & $\begin{array}{l}\text { IBD Circular No. } 02 \\
\text { of } 2004 .\end{array}$ & $\begin{array}{l}\text { General obligation to verify } \\
\text { Shariah compliance of banking } \\
\text { operations. The SSB must submit } \\
\text { an annual report to shareholders. }\end{array}$ & $\begin{array}{l}\text { Only one } \\
\text { advisor } \\
\text { required. A } \\
\text { board may be } \\
\text { set up at the } \\
\text { bank's } \\
\text { discretion. }\end{array}$ & Unspecified. & $\begin{array}{l}\text { Appointment must be } \\
\text { approved by State Bank of } \\
\text { Pakistan. }\end{array}$ & $\begin{array}{l}\text { They are compulsory and } \\
\text { relate to minimum } \\
\text { qualification and } \\
\text { experience, track record, } \\
\text { solvency, financial } \\
\text { integrity, honesty and } \\
\text { reputation and conflicts of } \\
\text { interests. }\end{array}$ \\
\hline Philippines & $\begin{array}{l}\text { Republic Act No. } \\
6848 \text { and Manual of } \\
\text { Regulations for } \\
\text { Banks-Implementing } \\
\text { Rules and } \\
\text { Regulations of } \\
\text { Republic Act No. } \\
6848\end{array}$ & $\begin{array}{l}\text { It offers advice and undertakes } \\
\text { reviews on matters relating to } \\
\text { Shariah compliance. }\end{array}$ & $\begin{array}{l}\text { At least three } \\
\text { but no more } \\
\text { than five } \\
\text { members. }\end{array}$ & Unspecified. & Unspecified. & $\begin{array}{l}\text { SSB members must be } \\
\text { Islamic scholars and } \\
\text { jurists of comparative law. }\end{array}$ \\
\hline Thailand & $\begin{array}{l}\text { Islamic Bank of } \\
\text { Thailand Act B.E } \\
2545 .\end{array}$ & $\begin{array}{l}\text { It has "the authority and duty to } \\
\text { give advice and recommendations } \\
\text { to the Board of Directors } \\
\text { concerning Islamic principles } \\
\text { related to the operation of the } \\
\text { bank". }\end{array}$ & $\begin{array}{l}\text { Not more than } \\
4 \text { members }\end{array}$ & $\begin{array}{l}\text { At least half of the } \\
\text { SSB members } \\
\text { form a quorum and } \\
\text { decisions are taken } \\
\text { by majority vote. }\end{array}$ & $\begin{array}{l}\text { SSB members have a two- } \\
\text { year tenure and may be } \\
\text { reappointed. They are } \\
\text { appointed and removed by } \\
\text { the board of directors. }\end{array}$ & $\begin{array}{l}\text { Financial integrity, } \\
\text { competence, honesty and } \\
\text { conflicts of interests. }\end{array}$ \\
\hline$U A E$ & $\begin{array}{l}\text { Federal Law No. } 6 \text { of } \\
1985\end{array}$ & $\begin{array}{l}\text { General obligation to verify } \\
\text { Shariah compliance of banking } \\
\text { operations. Detailed competences }\end{array}$ & $\begin{array}{l}\text { No less than } \\
\text { three }\end{array}$ & $\begin{array}{l}\text { To be decided in } \\
\text { the articles of } \\
\text { association of the }\end{array}$ & $\begin{array}{l}\text { SSB members must be } \\
\text { approved by the Higher } \\
\text { Shariah Authority }\end{array}$ & Unspecified \\
\hline
\end{tabular}


\begin{tabular}{|l|l|}
\hline & \\
\hline * Dubai International Financial Centre \\
\hline Soure: Oficial country websites and
\end{tabular}

to be established by the bank.

bank

Source: Official country websites and central bank Annual Reports 


\begin{tabular}{|c|c|c|c|c|}
\hline Country & $\begin{array}{c}\text { Separate Islamic } \\
\text { Banking \& Takaful } \\
\text { Department at CB }\end{array}$ & $\begin{array}{l}\text { Centralized SSB or High Shariah Authority or } \\
\text { Fatwa Board }\end{array}$ & $\begin{array}{l}\text { Islamic } \\
\text { Rating } \\
\text { Agency }\end{array}$ & $\begin{array}{l}\text { Separate Islamic Capital } \\
\text { Market Department within } \\
\text { Securities regulator }\end{array}$ \\
\hline Bahrain & $\begin{array}{l}\text { Yes, Islamic Financial } \\
\text { Institutions Supervision } \\
\text { Directorate }\end{array}$ & $\begin{array}{l}\text { No, but the International Islamic Financial Market is to promote } \\
\text { the harmonization and convergence of Shariah interpretations in } \\
\text { developing Islamic banking products and practices which are } \\
\text { universally acceptable }\end{array}$ & $\begin{array}{l}\text { No, but } \\
\text { International } \\
\text { Islamic Rating } \\
\text { Agency operates in } \\
\text { Bahrain }\end{array}$ & No \\
\hline Indonesia & $\begin{array}{l}\text { Yes, the Directorate of } \\
\text { Shariah Banking }\end{array}$ & $\begin{array}{l}\text { Yes, the National Shariah Board is authorized to issue fatwas } \\
\text { concerning products, services and operations of BIFS. It also } \\
\text { recommends Shariah advisors to BIFS }\end{array}$ & No & \\
\hline Jordan & No & No & No & No \\
\hline Kuwait & No & $\begin{array}{l}\text { The Fatwa Board in the Ministry of Awqaf and Islamic Affairs is } \\
\text { the final authority on Shariah disputes. Its advice is binding when } \\
\text { it arbitrates on disputes between members of the same SSB }\end{array}$ & No & No \\
\hline Sudan & $\begin{array}{l}\text { N/A, the whole financial } \\
\text { regulatory system is Islamic }\end{array}$ & $\begin{array}{l}\text { Yes, the Shariah High Supervisory Board is responsible for } \\
\text { fatwas, contract specimen, arbitrage, consultations relating to } \\
\text { Islamic legal aspects, training, research, lectures, and seminars }\end{array}$ & No & $\begin{array}{l}\text { N/A, the whole financial regulatory } \\
\text { system is Islamic }\end{array}$ \\
\hline Pakistan & $\begin{array}{l}\text { Yes, Islamic Banking } \\
\text { Department }\end{array}$ & $\begin{array}{l}\text { Yes, the Shariah Board of the State Bank is to advise the central } \\
\text { banks on matters of Shariah. It also produces specimen of } \\
\text { permissible Islamic Financial contract to ensure compliance with } \\
\text { minimum Shariah standards }\end{array}$ & No & $\begin{array}{l}\text { No, but several departments share } \\
\text { Islamic finance portfolio }\end{array}$ \\
\hline UAE & No & $\begin{array}{l}\text { Yes, the Higher Shariah Authority, attached to the Ministry of } \\
\text { Justice and Islamic Affairs, is the final arbiter on Shariah matters. } \\
\text { It is also responsible of Shariah supervision }\end{array}$ & No & No \\
\hline
\end{tabular}




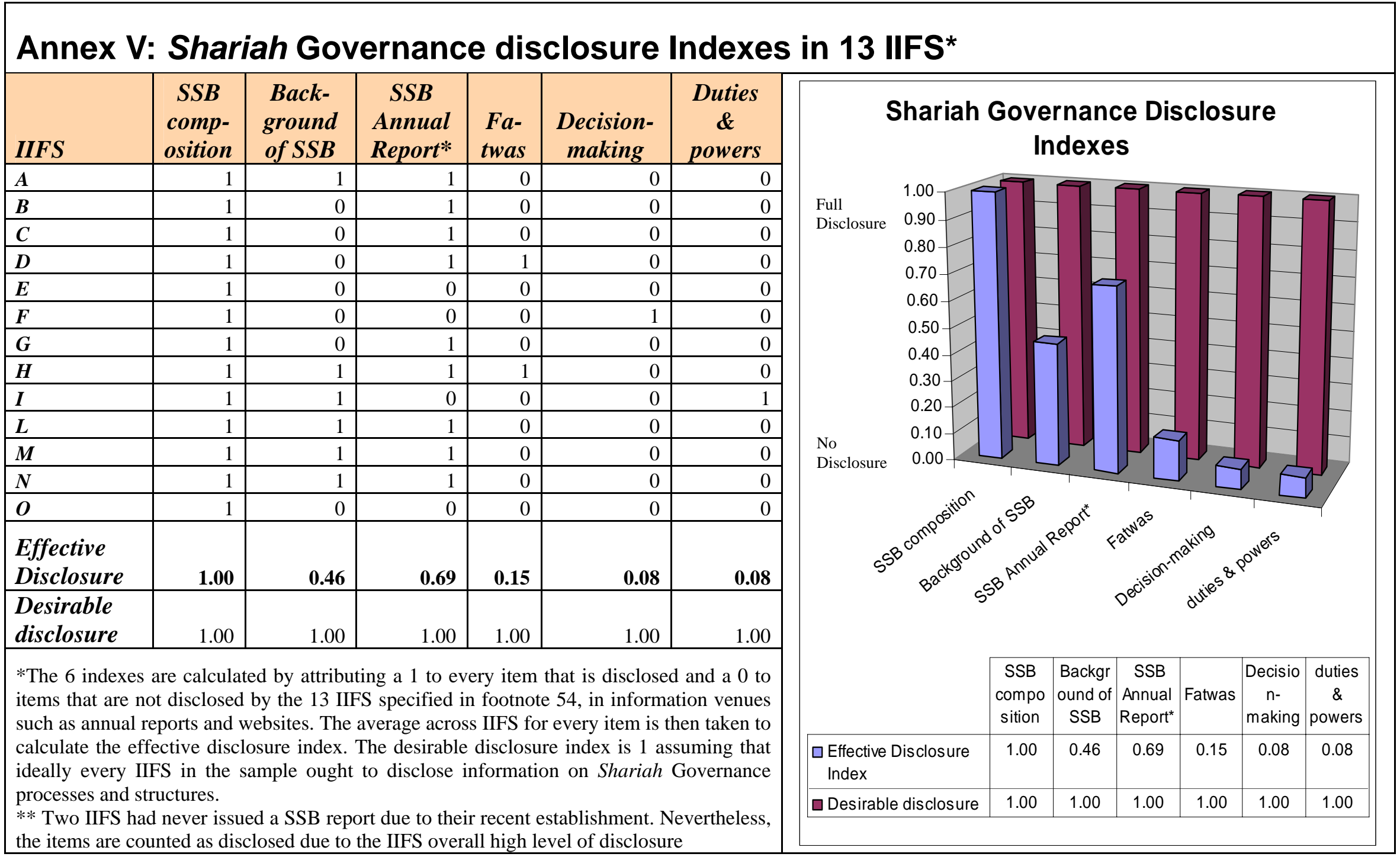


